\title{
Towards sustainable bioplastic production using the photoautotrophic bacterium Rhodopseudomonas palustris TIE-1
}

\author{
Tahina Onina Ranaivoarisoa ${ }^{1} \cdot$ Rajesh Singh $^{1} \cdot$ Karthikeyan Rengasamy $^{1} \cdot$ Michael S. Guzman $^{1} \cdot$ Arpita Bose $^{1}$ (i)
}

Received: 16 November 2018 / Accepted: 23 March 2019 / Published online: 29 March 2019

(c) The Author(s) 2019

\begin{abstract}
Bacterial synthesis of polyhydroxybutyrates (PHBs) is a potential approach for producing biodegradable plastics. This study assessed the ability of Rhodopseudomonas palustris TIE-1 to produce PHBs under various conditions. We focused on photoautotrophy using a poised electrode (photoelectroautotrophy) or ferrous iron (photoferroautotrophy) as electron donors. Growth conditions were tested with either ammonium chloride or dinitrogen gas as the nitrogen source. Although TIE-1's capacity to produce PHBs varied fairly under different conditions, photoelectroautotrophy and photoferroautotrophy showed the highest PHB electron yield and the highest specific PHB productivity, respectively. Gene expression analysis showed that there was no differential expression in PHB biosynthesis genes. This suggests that the variations in PHB accumulation might be post-transcriptionally regulated. This is the first study to systematically quantify the amount of PHB produced by a microbe via photoelectroautotrophy and photoferroautotrophy. This work could lead to sustainable bioproduction using abundant resources such as light, electricity, iron, and carbon dioxide.
\end{abstract}

Keywords Rhodopseudomonas palustris TIE-1 · Polyhydroxybutyrate · PHB · Photoferroautotrophy · Photoelectroautotrophy

\section{Introduction}

Polyhydroxybutyrates (PHBs) are the most well-studied members of the polyhydroxyalkanoates (PHAs), which is a family of biodegradable intracellular polyesters produced by several bacteria [38, 45, 67, 79, 85]. Due to its thermoresistance, moldability, and biodegradability, PHB is a promising substitute for conventional petroleum-derived plastics [11]. Because of its biocompatibility, PHB is also used in many medical applications such as drug delivery, reconstructive surgery and bone tissue scaffolding [48]. However, its production is currently underexploited due to high feedstock costs [67]. Heterotrophic microbes can be promising PHB producers as they can use low-cost carbon sources including

Electronic supplementary material The online version of this article (https://doi.org/10.1007/s10295-019-02165-7) contains supplementary material, which is available to authorized users.

Arpita Bose

abose@wustl.edu

1 Department of Biology, Washington University in St. Louis, One Brookings Drive, St. Louis, MO 63130, USA food wastes such as sugar beet, soy, and palm oil molasses [69]. However, the requirement for a continuous supply of food wastes makes them an infeasible source of carbon. Additional challenges of using food wastes are its sorting, transport, and pre-treatment prior to utilization [42, 54]. Lignocellulose from food [54] and forestry industries [41] or glycerol wastes from biofuel production have also been explored in heterotrophic PHB production $[4,75]$. Some studies have used pure substrates such as glucose, acetate, and ethanol [79]. However, due to the requirement of arable land, and direct competition with human food consumption, using these substrates for PHB production is not desirable [17]. These potential limitations of using heterotrophs eventually led to the investigation of autotrophs for PHB production [38].

A handful of studies have demonstrated autotrophs as efficient PHB producers over heterotrophs [30]. A chemoautotrophic hydrogen-oxidizing bacterium Ideonella spp. strain O-1 has been shown to produce PHB using industrial exhaust gas containing hydrogen $\left(\mathrm{H}_{2}\right)$, carbon dioxide $\left(\mathrm{CO}_{2}\right)$, and carbon monoxide $(\mathrm{CO})$. The exceptional ability of strain O-1 to grow even at CO concentration of 70\% (v/v) without suppression of PHB production made it an attractive 
candidate to produce PHB using industrial exhaust gas (rich in CO) [76]. However, this route of PHB production may not be ideal because of the high cost of operation, and the risk of explosion associated with the use of $\mathrm{H}_{2}$ [14]. A sulfatereducing bacterium Desulfococcus multivorans has also been shown to produce PHB [26], but its slow growth rate can make this process inefficient.

To make PHB bioproduction more efficient, economically viable and sustainable, research on autotrophic PHB production was further extended to photoautotrophs. The ability of photoautotrophs to use solar energy and $\mathrm{CO}_{2}$ for biosynthesis makes them unique candidates for efficient PHB synthesis $[19,34,74]$. Under photoautotrophic growth conditions, $\mathrm{CO}_{2}$ is fixed using energy harvested from light to generate ATP [9]. The fixed carbon can be used for the biosynthesis of acetyl-CoA, a substrate for PHB synthesis. In addition, photoautotrophs capable of fixing dinitrogen gas $\left(\mathrm{N}_{2}\right)$ using ATP generated by photosynthesis are even more desirable. Moreover, nitrogen limitation has been reported to increase PHB accumulation [34]. Indeed, a recent study reported the suitability of the photoautotrophic organism Synechocystis sp. PCC 6714 as a potential host strain for PHB production [34]. However, the PHB amount based on cell mass and volumetric productivity was very low [19].

To produce higher PHB with greater efficiency, research on bacterial PHB synthesis was further expanded to microbial electrosynthesis (MES). This approach is based on the ability of some autotrophs (also called electroautotrophs) to acquire electrons from solid-phase conductive substances (SPCSs) such as electrodes using them as electron donors. This process of using SPCSs as electron donors or acceptors is termed "extracellular electron transfer (EET)" [20, 23, 36, 66]. When microbes use SPCSs as electron donors, the form of EET they use is also called microbial electron uptake (EU). This capability of electroautotrophs has been leveraged to produce value-added multi-carbon products via MES by reducing $\mathrm{CO}_{2}$ via either indirect or direct EU. In direct EU, microorganisms attach to the electrode and directly take up electrons from them $[3,6,25,52,53,65,70,78,87$, 88], whereas indirect EU involves transport of electrons by diffusible electron careers such as $\mathrm{H}_{2}$, formate or ammonia (either produced electrochemically or added to the reactors) from the electrode to microbes $[13,18,28,33,39,43,58$, $62,68,72,80]$. Indirect EU has been successfully used for PHB bioproduction by the chemoautotroph Cupriavidus necator (previously named Ralstonia eutropha). Nishio et al. reported that PHB productivity in $C$. necator was enhanced by EET using a biocompatible mediator (2-poly (2-methacryloyloxyethyl phosphorylcholine-co-vinylferrocene) (PMF) in an electrochemical system with an anode that was poised at $+0.6 \mathrm{~V}$ vs. the standard hydrogen electrode (SHE). Here, the anode served as an additional electron acceptor for microbial metabolism, resulting in acceleration of glycolysis and hence PHB synthesis [55]. Indirect MES of PHB by $C$. necator using formate as an electron carrier has also been reported recently [12]. To enhance $\mathrm{CO}_{2}$ assimilation by $C$. necator, a formate dehydrogenase (FDH)-assisted MES system was constructed, in which FDH catalyzed the reduction of $\mathrm{CO}_{2}$ to formate in the cathodic chamber. Formate served as the electron carrier to transfer electrons into $C$. necator generating PHBs [12]. The involvement of mediators in indirect EU lowers the efficiency of product formation. Direct $\mathrm{EU}$ in the context of MES is desirable because it omits the extra steps involved in indirect EU [12, 55]. Although a thermodynamic evaluation of bacterial PHB production via MES was proposed nearly a decade ago [64], no pure microbial culture has been known to produce PHBs using MES via direct EU (i.e., without the use of mediators).

Due to the abundance of iron on earth [24], PHB production linked to autotrophy using ferrous iron, $\mathrm{Fe}(\mathrm{II})$, as an electron donor could be leveraged for sustainable PHB production. Some Fe(II)-oxidizing chemoautotrophs such as Gallionella ferruginea have been reported to accumulate PHBs intracellularly. However, quantitative measurements on PHB production have not been reported for this organism [27, 46, 83]. The use of oxygen as the terminal electron acceptor by these organisms is a challenge because oxygen reacts readily with $\mathrm{Fe}(\mathrm{II})$ to oxidize and precipitates it to $\mathrm{Fe}(\mathrm{III})$. Therefore, G. ferruginea can only oxidize iron under low-oxygen concentrations [46]. Photoautotrophs such as purple bacteria and green sulfur bacteria have been shown to oxidize $\mathrm{Fe}(\mathrm{II})$ while fixing $\mathrm{CO}_{2}$ using light via a process called photoferroautotrophy [21, 73]. Photoferroautotrophs are more attractive for PHB synthesis because they oxidize $\mathrm{Fe}(\mathrm{II})$ in the absence of oxygen. However, thus far PHB accumulation has not been demonstrated during photoferroautotrophic growth.

Here, Rhodopseudomonas palustris TIE-1 was chosen as a platform for PHB bioproduction because it demonstrates extraordinary metabolic versatility $[6,32]$. TIE- 1 can grow chemoheterotrophically in rich medium as well as photoheterotrophically using various organic carbon sources [32]. It can also use several inorganic electron donors such as $\mathrm{H}_{2}$ and thiosulfate for photoautotrophic growth [32]. More importantly, TIE- 1 is the only genetically tractable bacterium that has the ability to perform photoautotrophy using inorganic electron donors such as $\mathrm{Fe}$ (II) (photoferroautotrophy) and a poised electrode (photoelectroautotrophy) [6, 32]. TIE-1 performs direct EU to support photoelectrotrophy [6, 65]. These exceptional abilities make TIE- 1 a very promising candidate to study photoautotrophic PHB production under different growth conditions. We assessed PHB production quantitatively on several growth conditions and found that TIE-1 can produce PHBs both photoautotrophically and photoheterotrophically. Among the photoautotrophic growth conditions, the highest PHB electron yield [percentage of 
the electron (mol) from the substrate that was converted into PHBs] was obtained under photoelectroautotrophy, and the highest specific PHB productivity was obtained under photoferroautotrophy. These novel routes of PHB synthesis by TIE- 1 can potentially serve as a stepping stone for future bioengineering efforts towards sustainable PHB bioproduction.

\section{Materials and methods}

\section{Bacterial strain, media, and growth conditions}

Rhodopseudomonas palustris TIE-1 was originally isolated by Jiao et al. and has been used throughout this study [32]. For aerobic chemoheterotrophic growth, TIE-1 was routinely grown in $0.3 \%$ yeast extract and $0.3 \%$ peptone (YP) medium, with $10 \mathrm{mM}$ MOPS [3- $N$ (morpholino) propanesulfonic acid] at $\mathrm{pH} 7$ in the dark at $30{ }^{\circ} \mathrm{C}$ with shaking at $250 \mathrm{rpm}$. For growth on solid medium, YP medium was solidified with $1.5 \%$ agar supplemented with $10 \mathrm{mM}$ MOPS and $10 \mathrm{mM}$ sodium succinate. For anaerobic photoautotrophic growth, TIE-1 was grown in anaerobic bicarbonatebuffered freshwater (FW) medium [21] supplemented with ammonium chloride $\left(\mathrm{NH}_{4} \mathrm{Cl}\right)(5.61 \mathrm{mM})$ or mixed $\mathrm{N}_{2} / \mathrm{CO}_{2}$ $(80 \% / 20 \%)$ gas at a pressure of $34.5 \mathrm{kPa}$ as the sources of nitrogen. For anaerobic photoheterotrophic growth, $10 \mathrm{~mL}$ of FW medium was supplemented with anoxic $1 \mathrm{M}$ stocks of sodium succinate, sodium butyrate and sodium 3-hydroxybutyrate to a final concentration of $1 \mathrm{mM}$ in Balch tubes. However, to have higher biomass required for PHB, RNA and protein extraction, substrate concentrations were increased to $10 \mathrm{mM}$. A pre-grown TIE-1 culture with optical density $\left(\mathrm{OD}_{660}\right)$ of 1 was inoculated with a final $\mathrm{OD}_{660}$ of $0.01\left(100 \times\right.$ dilution) followed by incubation at $30^{\circ} \mathrm{C}$ in an environmental chamber fitted with infrared LED $(880 \mathrm{~nm})$. Time-course cell growth was monitored using Spectronic 200 (Thermo Fisher Scientific, USA). For photoautotrophic growth with $\mathrm{H}_{2}$ and $\mathrm{Fe}(\mathrm{II})$, TIE-1 was adapted to photoautotrophic growth using $\mathrm{H}_{2}$ as the sole electron donor as described previously [7]. For growth with $\mathrm{Fe}(\mathrm{II}), 50 \mathrm{~mL}$ of FW medium was prepared under the flow of $34.5 \mathrm{kPa} \mathrm{N} /$ $\mathrm{CO}_{2}(80 \% / 20 \%)$ and dispensed into pre-sterilized serum bottles purged with $34.5 \mathrm{kPa} \mathrm{N} / \mathrm{CO}_{2}(80 \% / 20 \%)$. The bottles were then sealed using sterile butyl rubber stoppers with aluminum crimp followed by the addition of anoxic sterile stocks of $\mathrm{FeCl}_{2}$ and nitrilotriacetic acid (NTA) to a final concentration of $5 \mathrm{mM}$ and $10 \mathrm{mM}$, respectively. All sample manipulations were performed inside an anaerobic chamber with $5 \% \mathrm{H}_{2} / 75 \% \mathrm{~N}_{2} / 20 \% \mathrm{CO}_{2}$ (Coy laboratory, Grass Lake) [7]. The bacterial generation time was determined as described previously [77]. Lag time (lag) was determined as a period that precedes the exponential phase [47].

\section{Cell enumeration}

Samples were fixed with paraformaldehyde $(20 \% \mathrm{v} / \mathrm{v})$, transferred into Amicon centrifuge filters (Amicon Ultracel $100 \mathrm{k}$, regenerated cellulose membrane, Millipore, Carrigtwohill, CO, Ireland) and centrifuged for $10 \mathrm{~min}$ at $1000 \times \mathrm{g}$. The pellets were resuspended and washed twice in PBS (phosphate-buffered saline). The cells were recovered by centrifugation at $3000 \times g$ for $15 \mathrm{~min}$. After the addition of PicoGreen ${ }^{\circledR}$ (Quant-iT PicoGreen ${ }^{\circledR}$ dsDNA, Life Technologies, Grand Island, NY, USA), the cells were counted in 96-well plates along with $50 \mu \mathrm{L}$ of Sphero ${ }^{\mathrm{TM}}$ AccuCount blank beads (Spherotech, Lake Forest, IL, USA). Cell density was estimated with an LSRII flow cytometer (BD, Sparks, MD, USA) using a 488-nm laser. A calibration curve relating the ratio of cell events to bead events and the cell density was constructed using a serial dilution of a cell sample. Density was then determined by microscopy (Helber Bacteria Cell counting chamber with Thoma ruling, Hawksley, Lancing, Sussex, UK). The $\mathrm{OD}_{660}$ of TIE-1 cells vs. cell numbers were plotted to obtain a standard curve.

\section{Bioelectrochemical setup and growth conditions}

All photoelectroautotrophic experiments were performed using a three-electrode configured seal-type bioelectrochemical cell (BEC, C001 Seal Electrolytic cell, Xi'an Yima Opto-electrical Technology Com., Ltd, China). The three electrodes were configured as the working electrode (graphite rod, $\left.3.2 \mathrm{~cm}^{2}\right)$, reference electrode $(\mathrm{Ag} / \mathrm{AgCl}$ in $3 \mathrm{M} \mathrm{KCl})$ and counter electrode ( $\mathrm{Pt}$ foil, $5 \mathrm{~cm}^{2}$ ). $70 \mathrm{~mL}$ of $\mathrm{FW}$ medium was dispensed into sterile BECs and made completely anaerobic by $\mathrm{N}_{2} / \mathrm{CO}_{2}(80 \% / 20 \%)$ bubbling for 60 min with the final pressure maintained at $\sim 50 \mathrm{kPa}$. $10 \mathrm{~mL}$ of TIE-1 cells $\left(\mathrm{OD}_{660} \sim 2.4\right)$ pre-grown in $\mathrm{FW}$ with $\mathrm{H}_{2}$ was then inoculated with a starting $\mathrm{OD}_{660} \sim 0.3$ as described previously [65]. The $\mathrm{OD}_{660}$ of the inoculated BECs was monitored with a BugLab Handheld OD Scanner (Applikon Biotechnology, Inc., Foster City, $\mathrm{CA}$ ). To evaluate the influence of $\mathrm{NH}_{4} \mathrm{Cl}$ and $\mathrm{N}_{2}$ gas as the nitrogen sources on PHB biosynthesis via photoelectroautotrophy, the BECs were operated simultaneously ( $c$ $=3$ biological replicates) with $\mathrm{NH}_{4} \mathrm{Cl}$ and $\mathrm{N}_{2}$ gas as nitrogen sources with negative controls: open-circuit (OC) control (no current) and abiotic controls. The graphite electrode was constantly poised at a potential of $+100 \mathrm{mV}$ vs. standard hydrogen electrode (SHE) for $130 \mathrm{~h}$ using a multichannel potentiostat (Interface 1000E, Gamry Multichannel Potentiostat, USA). All photoelectroautotrophic experiments were performed at $26{ }^{\circ} \mathrm{C}$ under continuous infrared light $(880 \mathrm{~nm})$ unless noted otherwise. At the end of the bioelectrochemical experiment, samples were immediately collected from the BEC reactors for RNA extraction and PHB production analysis as mentioned above. 


\section{Analytical procedures}

PHB measurement From all the growth conditions tested, $10 \mathrm{~mL}$ of bacterial samples at an $\mathrm{OD}_{660} 0.7$ (unless stated otherwise) was pelleted at $8000 \times \mathrm{g}$ for $10 \mathrm{~min}$ and stored at $-80{ }^{\circ} \mathrm{C}$ until PHB extraction and analysis were performed. $1 \mathrm{~mL}$ of water (LC-MS grade) and $600 \mu \mathrm{L}$ of methanol (HPLC grade) were added to arrest metabolic activity of TIE- $1.10 \mathrm{mg} / \mathrm{mL}$ of poly[(R)-3-hydroxybutyric acid] (Sigma-Aldrich, USA) was used as a PHB standard. Extraction of PHB was followed by its conversion to crotonic acid. The concentration of crotonic acid was measured using an Agilent Technologies 6420 Triple Quad LC/MS as follows: using Hypercarb column, particle $5 \mu \mathrm{m}, 100 \times 2.1 \mathrm{~mm}$ (Thermo Fisher Scientific, USA) as stationary phase; water with $0.1 \%(\mathrm{v} / \mathrm{v})$ formic acid as phase $\mathrm{A}$; acetonitrile and $1 \%(\mathrm{v} / \mathrm{v})$ formic acid as phase $\mathrm{B}$. The injection volume was $5 \mu \mathrm{L}$; the flow rate was set at $500 \mu \mathrm{L} \min ^{-1}$; the column temperature was set at $15^{\circ} \mathrm{C}$ and the gas temperature was $300{ }^{\circ} \mathrm{C}$ [31]. PHB was detected as crotonic acid with mass to charge ratio $(\mathrm{m} / \mathrm{z})=87$ which was normalized to bacterial cell number. Details on PHB extraction, PHB carbon yield, and PHB electron yield calculations are described in supplemental methods.

$\mathrm{H}_{2}$ and $\mathrm{CO}_{2}$ measurement Time-course $\mathrm{H}_{2}$ and $\mathrm{CO}_{2}$ from photoautotrophic conditions were analyzed using gas chromatography (Shimadzu BID 2010-plus, equipped with $\mathrm{Rt}^{\circledR}$-Silica BOND PLOT Column: $30 \mathrm{~m} \times 0.32 \mathrm{~mm}$; Restek, USA) with helium as a carrier gas. At each time point, $10 \mu \mathrm{L}$ of gas was sampled from the headspace of the serum bottles using a Hamilton ${ }^{\mathrm{TM}}$ gas-tight syringe and injected into the column. To quantify dissolved $\mathrm{CO}_{2}, 1 \mathrm{~mL}$ of filtered (using $0.22 \mu \mathrm{m}$ PES membrane filter) aqueous samples from each reactor was collected and injected into helium-evacuated 12-mL septum-capped glass vials (Exetainer, Labco, Houston, TX, USA) containing $1 \mathrm{~mL}$ of $85 \%$ phosphoric acid. The concentration of the dissolved $\mathrm{CO}_{2}$ was then measured by injecting $10 \mu \mathrm{L}$ of evolved $\mathrm{CO}_{2}$ in the headspace into the column. The total $\mathrm{CO}_{2}$ in the reactors was calculated as described previously [50].

Organic acid measurement Time-course consumption of organic acids such as sodium succinate, sodium butyrate, and sodium 3-hydroxybutyrate under photoheterotrophic conditions were quantified using an Ion Chromatography Metrohm 881 Compact Pro using a Metrosep organic acid column ( $250 \mathrm{~mm}$ length). $0.5 \mathrm{mM} \mathrm{H}_{2} \mathrm{SO}_{4}$ with $15 \%$ acetone was used as eluent at a flow rate of $0.4 \mathrm{~mL} \mathrm{~min}^{-1}$ with suppression (10 $\mathrm{mM} \mathrm{LiCl}$ regenerant).

$\mathrm{Fe}(\mathrm{II})$ measurement Time-course $\mathrm{Fe}(\mathrm{II})$ concentration was measured using the Ferrozine Assay as described previously [7].

Total protein measurement Total protein during photoferroautotrophy was measured using trichloroacetic acid (TCA) precipitation as follows: total protein from $2 \mathrm{~mL}$ culture (at time point zero and at $192 \mathrm{~h}$ for the growth with $\mathrm{NH}_{4} \mathrm{Cl}$ and $360 \mathrm{~h}$ with $\mathrm{N}_{2}$ gas) in microcentrifuge tube was precipitated using $500 \mu \mathrm{L} 100 \%$ TCA. This mixture was incubated for $10 \mathrm{~min}$ at $4{ }^{\circ} \mathrm{C}$ and centrifuged at $18,000 \times \mathrm{g}$ for $30 \mathrm{~min}$ at $4{ }^{\circ} \mathrm{C}$. The pellet was washed with $200 \mu \mathrm{L}$ cold acetone and centrifuged at $18,000 \times g$ for $10 \mathrm{~min}$ at $4{ }^{\circ} \mathrm{C}$. The pellet was then dried at $95{ }^{\circ} \mathrm{C}$ for 10 min to remove any residual acetone and resuspended in $50 \mu \mathrm{L} \mathrm{HCl}$ buffered with $100 \mathrm{mM}$ Tris-Cl, pH 8.0. The BCA (bicinchoninic acid) Protein Assay Kit was employed using the microtiter plate method for protein estimation as specified by the manufacturer's protocol following TCA precipitation (Thermo Scientific, Waltham, MA). Total protein was measured at an absorbance of $562 \mathrm{~nm}$ using the Biotek Synergy HTXmicrotiter plate reader [7]. For a total protein to $\mathrm{OD}_{660}$ conversion, total protein of known $\mathrm{OD}_{660}$ values of TIE-1 cells was quantified. A standard curve was obtained by plotting $\mathrm{OD}_{660}$ vs. total protein measured.

\section{RNA extraction and sequencing}

$5 \mathrm{~mL}$ of bacterial culture were collected at an $\mathrm{OD}_{660} \sim 0.7$. The RNA was stabilized using $5 \mathrm{~mL}$ RNAlater (Qiagen, USA) (buffer that stabilizes and protects RNA from degradation) and incubated at room temperature for $10 \mathrm{~min}$. Bacterial cells were centrifuged at $5000 \times g$ for $10 \mathrm{~min}$ and pellets were stored at $-80^{\circ} \mathrm{C}$ until RNA extraction was performed. RNA extraction was performed using the RNeasy Mini Kit (Qiagen, USA) following the manufacturer's protocol. DNA removal was performed using the Turbo DNA-free Treatment and Removal Kit (Ambion, USA). DNA contamination was tested using PCR using the primers listed in Table $\mathrm{S} 1$ as previously described $[6,7]$. Illumina unpaired 150-bp libraries were prepared and sequenced at the Genome Technology Access Center, Washington University on an Illumina MiSeq platform (Illumina Inc., San Diego, CA, USA). Trimmomatic (version 0.36) was used to remove Illumina sequencing adapters, quality trim deteriorating bases (threshold $=20)$, and length filter ( $\min =60 \mathrm{bp}$ ) [5]. Preprocessed RNA-seq reads were mapped to the published $R$. palustris TIE-1 genome using TopHat2 (version 2.1.1) (https://genomebiology.biomedcentral.com/artic les/10.1186/gb-2013-14-4r36) and the gff3 annotation file as a guide for sequence alignment. Bowtie 2 (version 2.3.3.1). (https://www.ncbi.nlm.nih.gov/pmc/articles/PMC3322381 /) was used to index the reference genome FASTA file. The number of reads mapping to each feature was counted by HTSeq (version 0.9.1). Differentially expressed genes were predicted in DESEQ 2 (version 1.16.1) using the HTSeq (https://www.ncbi.nlm.nih.gov/pubmed/25260700) read counts and an adjusted $p$ value cutoff of 0.05 . Heat maps were drawn in $\mathrm{R}$ using ggplot2 [44, 82]. 


\section{Reverse transcription quantitative $P C R$ analysis (RT-qPCR)}

cDNA template was synthesized using the purified RNA samples using the iScript cDNA Synthesis Kit (Biorad, USA). Primers listed in (Table S2) were designed using primer3 software (http://bioinfo.ut.ee/primer3/). RT-qPCR was performed using Biorad CFX connect Real-Time System Model \# Optics ModuleA using the following thermal cycling conditions: 1 cycle at $95{ }^{\circ} \mathrm{C}$ for $3 \mathrm{~min}$ and 30 cycles of $95^{\circ} \mathrm{C}$ for $3 \mathrm{~s}, 60^{\circ} \mathrm{C}$ for $3 \mathrm{~min}$, and $65^{\circ} \mathrm{C}$ for $5 \mathrm{~s}$ according to the manufacturer's protocol. Fold change comparison and standard deviation calculations were performed as described previously [2].

\section{Identification of PHB cycle genes of TIE-1}

The available TIE-1 genome in the JGI Genome Portal (https://genome.jgi.doe.gov/) was used to search for homolog genes involved in the PHB cycle using Blast search.

\section{Scanning transmission electron microscopy- electron energy loss spectroscopy (STEM-EELS)}

TIE-1 grown under sodium butyrate, Fe(II)-NTA and poised graphite electrode was used as representative samples for STEM-EELS. Briefly, $5 \mathrm{~mL}$ planktonic cell suspensions were centrifuged at $6000 \times g$ for $5 \mathrm{~min}$. followed primary fixation by resuspending the cells pellets in $2 \%$ formaldehyde and $2.5 \%$ glutaraldehyde in $0.05 \mathrm{M}$ sodium cacodylate buffer ( $\mathrm{pH} 7.2$ ) for $45 \mathrm{~min}$ at room temperature. After agar encapsulation followed by primary fixation for $\sim 20 \mathrm{~min}$, agar cubes were subjected to secondary fixation for $\sim 5 \mathrm{~h}$ followed by acetone dehydration and resin infiltration. Ultrathin sections $(\sim 50-60 \mathrm{~nm})$ were obtained using Reichert Ultracut UCT ultramicrotome (Donald Danforth Plant Science Center, Saint Louis, MO), then mounted directly on amorphous-carbon film-coated TEM $\mathrm{Cu}$-grids. Intracellularly localized PHB granules were characterized using a JEOL JEM-2100F field emission scanning transmission electron microscopy (FE-STEM) with an accelerating voltage of $200 \mathrm{keV}$ (Institute of Material Science and Engineering, WUSTL); the microscope is attached with a Gatan 805 BF/DF detector, Gatan 806 HAADF detector and Gatan 863 Tridiem imaging filter (GIF) system. Images were obtained in STEM mode using HAADF detector and BF detector. EELS spectral images were acquired through working HAADF and GIF jointly. Carbon-K edge and nitrogen-K edge elemental maps were retrieved from STEM-EELS spectral images.

\section{Statistical analysis}

The $P$ values were determined by one-way ANOVA followed by a pairwise test with Bonferroni adjustment. For the pairwise test with Bonferroni adjustment, the cutoff $P$ value is equal to 0.025

\section{Nucleotide sequence accession numbers}

All RNAseq datasets have been deposited in NCBI under BioProject accession number PRJNA417278.

\section{Results and discussion}

\section{Rhodopseudomonas palustris TIE-1 possesses putative PHB cycle genes}

PHB production has been previously reported by several $R$. palustris strains $[15,51,84]$. However, the PHB cycle genes have not been explored thus far. This lack of information critically limits the potential prospects for future bioengineering efforts for PHB bioproduction. Availability of the TIE-1 genome allowed us to identify the genes that are homologous to the PHB cycle genes of $C$. necator $[59,60$, 81], an $\mathrm{H}_{2}$-oxidizing betaproteobacterium that is known to produce and sequester PHAs intracellularly [8]. Reconstruction of the PHB cycle in E. coli using PHB genes from $C$. necator has been previously used to elucidate the biochemical pathway of PHB production and its subsequent metabolism [81]. Briefly, the pathway starts with the condensation of two acetyl-CoAs into acetoacetyl-CoA, a reaction driven by the $\beta$-ketothiolase enzyme, PhaA [81] (Fig. 1a). Acetoacetyl-CoA gets reduced to $(R)-3$-hydroxybutyryl-CoA by the enzyme acetoacetyl-CoA reductase, PhaB. Eventually, PHB polymerization is achieved by the $\mathrm{PHB}$ polymerase, $\mathrm{PhaC}$ (Fig. 1a). Interestingly, PHB can also serve as an important source of carbon and energy during environmental stress, where PHB molecules are catabolized by the PHB depolymerase, PhaZ (Fig. 1a) [81]. In Bradyrhizobium diazoefficiens, a nitrogen-fixing symbiont closely related to TIE1 , PhaR represses the expression of $p h a C_{1}$ and $p h a C_{2}$. In addition, $\mathrm{PhaR}$ regulates $\mathrm{PhaP}$, the phasin protein that binds to and controls the number and size of the PHB granules. PhaR also binds to PHB granules and dissociates from it as the granule size grows [63]. TIE-1 encodes one phaR gene (Rpal_0531); one phaZ gene (Rpal_0578); multiple copies of phaA and phaB; two copies of phaC (Rpal_2780 and Rpal_4722); and three genes for phaP 2 (Rpal_4291, 4616 and 4617) (Fig. 1a, b). A phaB gene (Rpal_0533) is located next to the phaA gene (Rpal_0532) (Fig. 1b) forming a putative operon (Fig. 1b). The gene for phaR (Rpal_0531) 
(a)

Carbon Sources: Organic carbon, carbon dioxide

Nitrogen Source: Ammonium chloride, nitrogen gas

Electron Donor: Organic carbon, hydrogen, ferrous iron, poised electrode

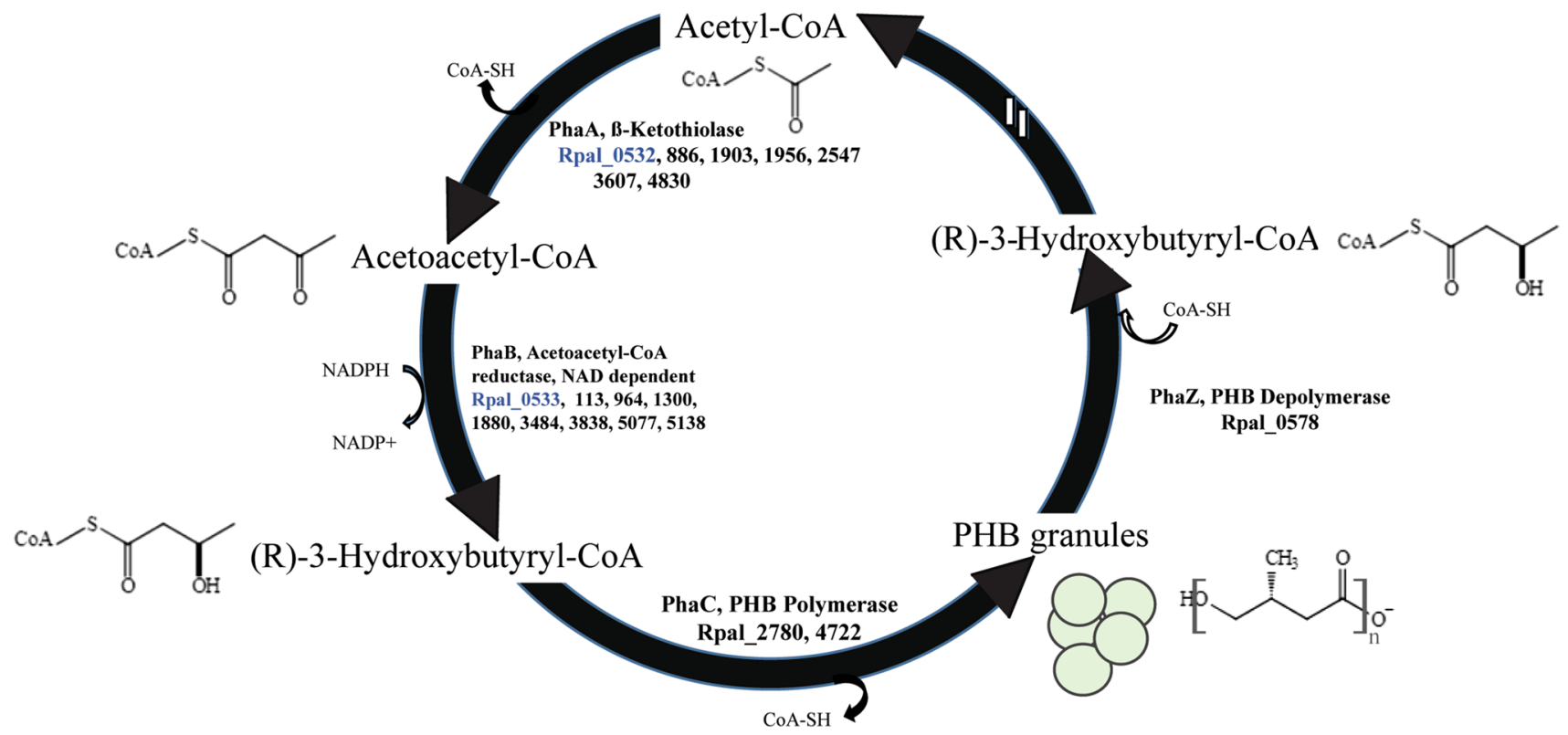

(b)

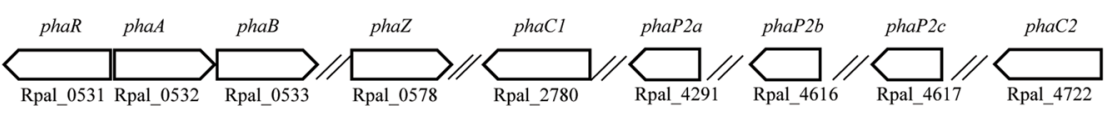

Fig. 1 The PHB cycle and its putative genes in TIE-1. a Putative PHB cycle of TIE-1. Acetyl-CoA is produced using multiple carbon sources such as organic carbon or carbon dioxide $\left(\mathrm{CO}_{2}\right)$ followed by the condensation of two acetyl-CoAs into acetoacetyl-CoA. Acetoacetyl-CoA gets reduced to $(R)$-3-hydroxybutyryl-CoA by the enzyme acetoacetyl-CoA reductase, PhaB. $(R)-3$-Hydroxybutyryl-CoA is

is positioned next to the phaA (Rpal_0532) gene in this operon but expressed from the opposite strand. This shows that TIE-1 possesses all the necessary genes for both PHB biosynthesis, polymerization and depolymerization.

\section{TIE-1 produces PHB under photoautotrophic conditions using different electron donors}

\section{Photoautotrophic PHB production using $\mathrm{H}_{2}$ as an electron donor}

TIE-1 was grown with $\mathrm{H}_{2}$ as the sole electron donor with $\mathrm{N}_{2}$ and $\mathrm{NH}_{4} \mathrm{Cl}$ as fixed nitrogen sources. We call the $\mathrm{N}_{2}$ fixing conditions as the electron donor- $\mathrm{N}_{2}$ system and the $\mathrm{NH}_{4} \mathrm{Cl}$ conditions as the electron donor- $\mathrm{NH}_{4} \mathrm{Cl}$ system throughout. TIE-1 showed a higher maximum $\mathrm{OD}_{660}$ of $1.16(P \leq 0.001$, Table 1) with $\mathrm{NH}_{4} \mathrm{Cl}\left(\mathrm{H}_{2}-\mathrm{NH}_{4} \mathrm{Cl}\right.$ system) compared to $\mathrm{OD}_{660}$ of 0.54 with $\mathrm{N}_{2}\left(\mathrm{H}_{2}-\mathrm{N}_{2}\right.$ system). This growth defect observed in $\mathrm{H}_{2}-\mathrm{N}_{2}$ was also reflected in the longer generation time of eventually polymerized into $\mathrm{PHB}$ granules by $\mathrm{PhaC}_{1}$ and/or $\mathrm{PhaC}_{2}$. During carbon storage mobilization, $\mathrm{PHB}$ is degraded back to (R)3-hydroxybutyryl-CoA, and then to acetyl-CoA by multiple enzymatic reactions (shown by the double white lines). b Organization of the genes involved in the putative PHB cycle in TIE-1. Adapted from [81]

$41 \mathrm{~h}$ in the $\mathrm{H}_{2}-\mathrm{N}_{2}$ system compared to $34 \mathrm{~h}$ in the $\mathrm{H}_{2}-\mathrm{NH}_{4} \mathrm{Cl}$ system $(P=0.005$, Table 1$)$. Slow growth under $\mathrm{N}_{2}$ fixing conditions was previously observed in $R$. palustris strain 42 OL [15] and is likely due to the high-energy requirement of this process. TIE-1 showed a lower PHB carbon yield [percentage of carbon (mol) from the substrate that was converted into PHBs] of $2.55 \%$ in the $\mathrm{H}_{2}-\mathrm{N}_{2}$ system compared to the $\sim 3$ times higher yield of $7.23 \%$ in the $\mathrm{H}_{2}-\mathrm{NH}_{4} \mathrm{Cl}$ system. In contrast, no significant difference was observed in PHB electron yield [percentage of the electron (mol) from the substrate that was converted into PHBs] between the $\mathrm{H}_{2}-\mathrm{N}_{2}$ system and the $\mathrm{H}_{2}-\mathrm{NH}_{4} \mathrm{Cl}$ system (Fig. 2a, Table 2). Interestingly, the specific PHB productivity almost doubled in the $\mathrm{H}_{2}-\mathrm{N}_{2}$ system compared to the $\mathrm{H}_{2}-\mathrm{NH}_{4} \mathrm{Cl}$ system (from $1.30 \times 10^{-14}$ to $3.08 \times 10^{-14} \mathrm{mg} / \mathrm{L} / \mathrm{Cell} / \mathrm{h}$ ) (Table 2). The higher specific productivity under $\mathrm{N}_{2}$ fixing conditions and the growth defect (Table 1) indicate a direct impact of stress caused by the high-energy-consuming $\mathrm{N}_{2}$ fixation process. This stress might have induced TIE-1 to accumulate intracellular PHBs 
Table $1 R$. palustris TIE-1 growth in different conditions

\begin{tabular}{|c|c|c|c|c|c|c|c|c|}
\hline Growth conditions & Lag time $(\mathrm{h})$ & $P$ & Generation time(h) & $P$ & $\operatorname{Max} \mathrm{OD}_{660}$ & $P$ & $\begin{array}{l}\text { Time to } \\
\text { achieve max } \\
\mathrm{OD}_{660}(\mathrm{~h})\end{array}$ & $P$ \\
\hline YP & $16(0.0)$ & & $11.18(1.1)$ & & $0.43(0.01)$ & & $58(0.0)$ & \\
\hline Succinate $\left(\mathrm{NH}_{4} \mathrm{Cl}\right)$ & $34.6(6.1)$ & $5.4 \times 10^{-5}$ & $7.7(0.4)$ & 0.218 & $0.27(0.01)$ & 0.669 & $79(2.3)$ & $2.11 \times 10^{-6}$ \\
\hline Succinate $\left(\mathrm{N}_{2}\right)$ & $117.3(5.0)$ & & $8.7(1.1)$ & & $0.27(0.00)$ & & $138(0)$ & \\
\hline Butyrate $\left(\mathrm{NH}_{4} \mathrm{Cl}\right)$ & $21.3(2.3)$ & $0.11 \times 10^{-5}$ & $5.3(0.2)$ & 0.01 & $0.42(0.03)$ & 0.0023 & $62(0.0)$ & $0.60 \times 10^{-6}$ \\
\hline Butyrate $\left(\mathrm{N}_{2}\right)$ & $110.6(2.3)$ & & $7.1(0.5)$ & & $0.69(0.00)$ & & $137(2)$ & \\
\hline 3-Hydroxybutyrate $\left(\mathrm{NH}_{4} \mathrm{Cl}\right)$ & $10.6(2.3)$ & $3.23 \times 10^{-5}$ & $8.4(1.1)$ & 1 & $0.34(0.02)$ & 0.946 & $70 \pm 0$ & $3.19 \times 10^{-6}$ \\
\hline 3-Hydroxybutyrate $\left(\mathrm{N}_{2}\right)$ & $88.6(6.11)$ & & $14.6(5.8)$ & & $0.34(0.030$ & & $119(2)$ & \\
\hline $\mathrm{H}_{2}\left(\mathrm{NH}_{4} \mathrm{Cl}\right)$ & $25.3(2.3)$ & $1.30 \times 10^{-5}$ & $34(7.0)$ & 0.005 & $1.16(0.01)$ & 0.000 & $428(0)$ & 0.001 \\
\hline $\mathrm{H}_{2}\left(\mathrm{~N}_{2}\right)$ & $60.0(0)$ & & $41(5.0)$ & & $0.54(0.04)$ & & $308(28)$ & \\
\hline Iron (II) $\left(\mathrm{NH}_{4} \mathrm{Cl}\right)$ & NM (1) & NM (1) & $27.4(0.6)$ & $7.48 \times 10^{-5}$ & $0.25(0.02)$ & 0.006 & $192(0.00)$ & 0.000 \\
\hline Iron (II) $\left(\mathrm{N}_{2}\right)$ & NM (1) & & $49.1(15.9)$ & & $0.14(0.02)$ & & $360(0.00)$ & \\
\hline $\begin{array}{l}\text { Photoelectroautotrophy } \\
\left(\mathrm{NH}_{4} \mathrm{Cl}\right)\end{array}$ & NM (2) & NM (2) & $76(10.0)$ & 0.086 & $0.73(0.06)$ & 0.021 & $96(0.00)^{\mathrm{a}}$ & 0 \\
\hline Photoelectroautotrophy $\left(\mathrm{N}_{2}\right)$ & NM (2) & & $82(8.0)$ & & $0.61(0.01)$ & & $96(0.00)^{\mathrm{a}}$ & \\
\hline $\begin{array}{l}\text { Photoelectroautotrophy open } \\
\text { circuit }\left(\mathrm{NH}_{4} \mathrm{Cl}\right)\end{array}$ & NM (3) & NM (3) & NM (3) & NM & $0.25(0.014)$ & 0.066 & $96(0.00)^{\mathrm{a}}$ & 0 \\
\hline $\begin{array}{l}\text { Photoelectroautotrophy open } \\
\text { circuit }\left(\mathrm{N}_{2}\right)\end{array}$ & NM (3) & & NM (3) & & $0.22(0.014)$ & & $96(0.00)^{\mathrm{a}}$ & \\
\hline
\end{tabular}

NM (1) = not measurable, bacterial measurements were performed at time zero and time final by total protein conversion to OD; hence lag time could not be measured. NM (2)= not measurable; bacteria were preadapted to hydrogen growth and the inoculum was higher, which led to cells immediately entering exponential phase without lag time. NM (3)=not measurable; bacteria were incubated in the absence of electron donor. Therefore, no growth was observed

$\mathrm{NH}_{4} \mathrm{Cl}$ with ammonium chloride, $\mathrm{N}_{2}$ nitrogen-fixing condition

$P$ values are between growth with $\mathrm{NH}_{4} \mathrm{Cl}$ and $\mathrm{N}_{2}$ fixing conditions

${ }^{\text {a }}$ The experiment was terminated after $96 \mathrm{~h},()=$ standard deviation values from $n=3$

(a) Photoautotrophic Conditions

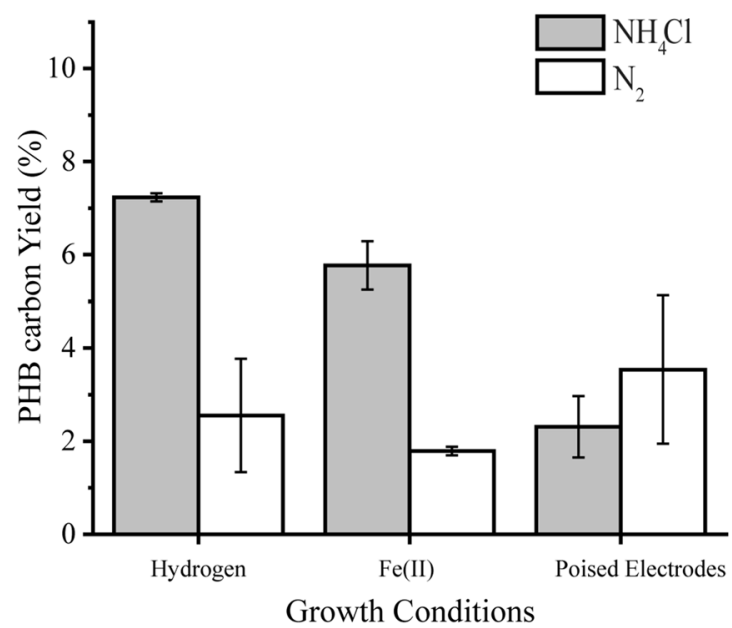

Fig. 2 PHB carbon yield by TIE- 1 grown in freshwater (FW) medium with ammonium chloride $\left(\mathrm{NH}_{4} \mathrm{Cl}\right)$ or under $\mathrm{N}_{2}$ fixing conditions $\left(\mathrm{N}_{2}\right.$ gas). a Photoautotrophic conditions with $\mathrm{H}_{2}, \mathrm{Fe}(\mathrm{II})$ (photoferroautotrophy) or poised electrodes (photoelectroautotrophy) as electron donors; b photoheterotrophic conditions with succinate, butyrate or 3-hydroxybutyrate as electron donors. Error bars are from the stand- (b) Photoheterotrophic Conditions

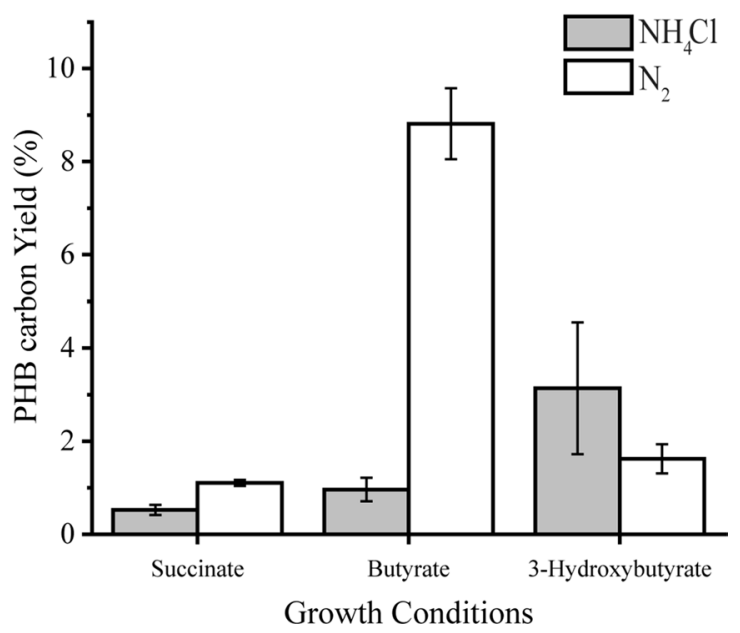

ard deviations calculated using 2-3 biological replicates as specified in Table 2. The $P$ values were determined by one-way ANOVA followed by a pairwise test with Bonferroni adjustment; $n s$ not significant. For a pairwise test, the cutoff $P$ value is 0.025 . $P$ values are indicated in Tables 2, S5 


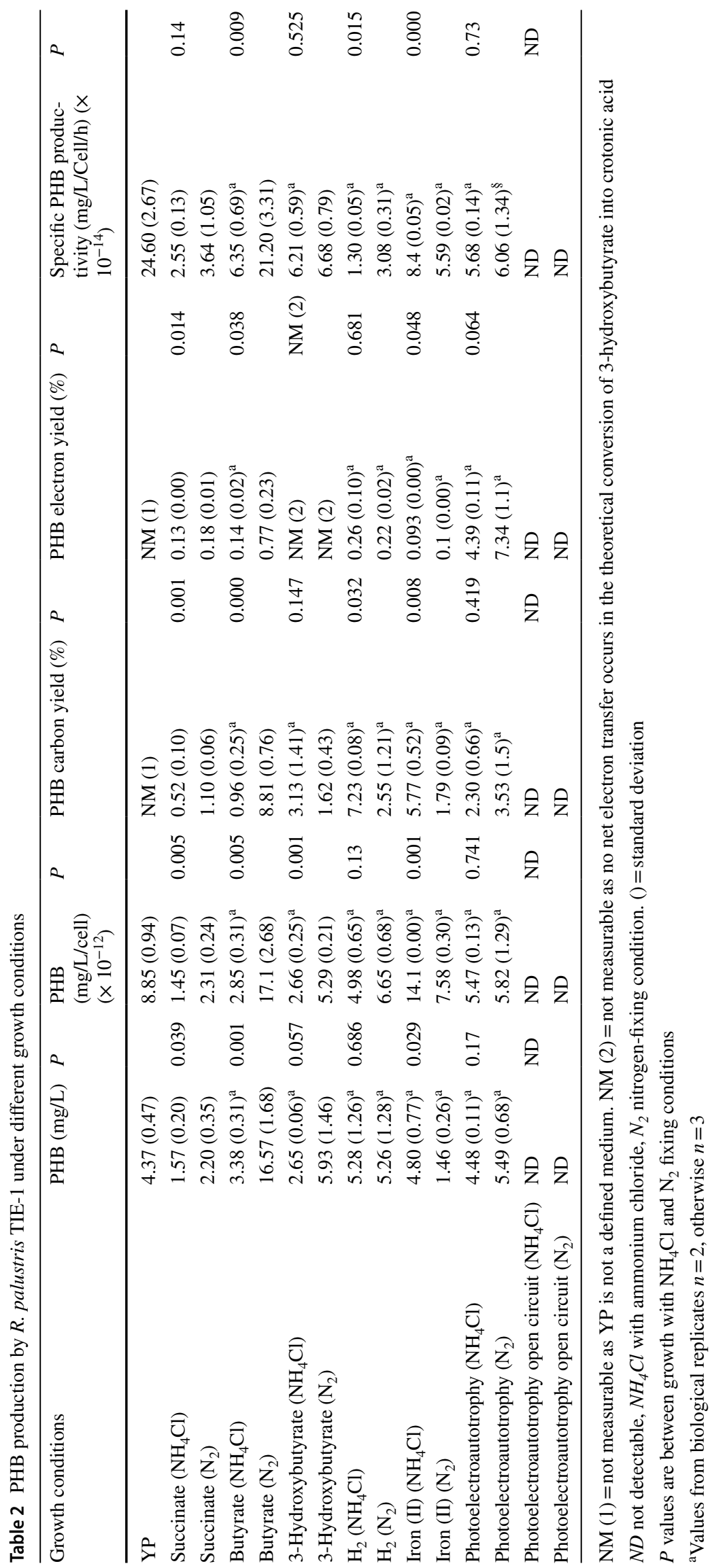


as a carbon and energy reserve. Similar observations have been reported for other purple non-sulfur bacteria [29] grown under nitrogen-limited conditions, including $R$. palustris strains grown in nitrogen-deprived conditions [51]. Increased accumulation of PHB to over $30 \%$ of the dry cell weight was observed previously when $R$. palustris CGA009 cells were $\mathrm{N}_{2}$ starved [51]. Because $\mathrm{H}_{2}$ is known to be produced during $\mathrm{N}_{2}$ deprivation by CGA009 [51], this $\mathrm{H}_{2}$ could serve as an additional electron donor for photoautotrophy, accounting for additional PHB accumulation. Further studies will be required to test whether this is happening in CGA009 and TIE-1. Although the growth with $\mathrm{NH}_{4} \mathrm{Cl}$ had $\mathrm{N}_{2}$ gas in the headspace under most conditions in our experiment, the presence of $\mathrm{NH}_{4} \mathrm{Cl}$ has been known to inhibit nitrogenase gene expression, preventing $\mathrm{N}_{2}$ fixation from occurring in the presence of $\mathrm{NH}_{4} \mathrm{Cl}$ [40].

\section{Photoautotrophic PHB production using a poised electrode as an electron donor}

To evaluate PHB production under photoelectroautotrophy using poised electrodes as the sole electron donor, graphite electrodes were poised at a potential $+100 \mathrm{mV}$ vs. SHE to mimic the $\mathrm{Fe}(\mathrm{OH})_{3} / \mathrm{Fe}^{2+}$ redox couple. Although the electrode- $\mathrm{NH}_{4} \mathrm{Cl}$ system resulted in higher maximum $\mathrm{OD}_{660}$ compared to the electrode- $\mathrm{N}_{2}$ system ( 0.73 vs. 0.61 , respectively) (Table 1 ), there was no significant difference in the generation time of TIE-1 between these two conditions (Fig. 3a; Table 1). Nonetheless, after $96 \mathrm{~h}$ of incubation, EU by TIE- 1 in the electrode- $\mathrm{NH}_{4} \mathrm{Cl}$ system was $1.92 \mu \mathrm{A} / \mathrm{cm}^{2}$, about double of that obtained in the electrode- $\mathrm{N}_{2}$ with an $\mathrm{EU}$ of $0.93 \mu \mathrm{A} / \mathrm{cm}^{2}$ (Fig. 3b, Table S6, $P \leq 0.01$ ). Despite the difference in the total $\mathrm{EU}$, no notable change was observed in the PHB carbon yield, PHB electron yield and specific PHB productivity between the electrode- $\mathrm{NH}_{4} \mathrm{Cl}$ system and the electrode- $\mathrm{N}_{2}$ system (Fig. 2a; Table 2). This result could be due to the continuous supply of electrons from a poised electrode, which did not seem to directly impact PHB biosynthesis. As expected, no cell growth was observed in the biotic reactors with unpoised electrodes (open circuit, OC) with both $\mathrm{NH}_{4} \mathrm{Cl}$ and $\mathrm{N}_{2}$ gas (Fig. 3a). Abiotic controls did not show any EU (Fig. 3b). Bioelectrosynthesis of PHB has been recently reported via a method using enzymatic and electrochemical approaches. A modified electrode poised at $-386 \mathrm{mV}$ vs. SHE was used to synthesize NADH in the presence of enzymes of the PHB cycle to convert acetate to PHB. The amount of PHB produced was $0.3 \mathrm{mg} / \mathrm{L}$ (under a maximum current density $\left(J_{\max }\right)$ of $27.9 \pm 1.3 \mu \mathrm{A} \mathrm{cm} \mathrm{cm}^{-2}$ ) [1]. In another study, $226 \pm 6 \mathrm{mg} / \mathrm{L}$ of PHB was produced via indirect EU using formate as a mediator by $C$. necator (Ralstonia eutropha) at $-395 \mathrm{mV}$ vs. SHE $\left(\sim J_{\max } 213\right.$ $\mu \mathrm{A} \mathrm{cm}^{-2}$ ) [12]. In addition, overexpression of the ruBisCO
(Ribulose-1,5-bisphosphate carboxylase/oxygenase) gene was performed to increase the $\mathrm{CO}_{2}$ fixation [12]. As a result, PHB production was enhanced to $485 \mathrm{mg} / \mathrm{L}$ [12]. However, both of these approaches involve multiple steps including enzyme purification. They also operate at a higher reduction potential than what we use to grow TIE-1 for PHB production (+ $100 \mathrm{mV}$ vs. SHE, $J_{\max }$ of only $<2 \mu \mathrm{A} \mathrm{cm} \mathrm{cm}^{-2}$ ). Although our results show a low $(\sim 5-6 \mathrm{mg} / \mathrm{L})$ amount of PHB production under photoelectroautotrophy via direct MES, our approach offers numerous advantages: (1) using direct EU, we minimize the complexity of the MES system; (2) TIE-1 grows at a lower reduction potential than that used in the studies above. This lower reduction potential ultimately saves electrical energy; and (3) TIE-1 is a photoautotroph and, therefore, can use the energy of light to make excess ATP for biosynthesis. The photoautotrophic ability of TIE-1 makes is especially attractive for sustainable PHB bioproduction because light is an abundant resource. The major hurdle for using TIE-1 for bioproduction is the low electron uptake it demonstrates from graphite electrodes. This is reflected in the lower maximum current density $\left(J_{\max }\right)$ values that were observed here in our study. Improving electron uptake would increase $J_{\max }$ values, which would also increase bioproduction [65]. A previous study from our laboratory has shown that inexpensive electrode modifications such as coating the electrodes with Prussian Blue can enhance electron uptake in the absence of a mediator via direct EU [65]. We are pursuing reactor design and electrode modifications further to enhance direct EU by TIE-1 because that will ultimately improve product formation.

\section{Photoautotrophic PHB production using ferrous iron as an electron donor}

Specific PHB productivity was higher in the $\mathrm{H}_{2}-\mathrm{N}_{2}$ compared to the $\mathrm{H}_{2}-\mathrm{NH}_{4} \mathrm{Cl}$ systems (Table 2) but no difference was observed under photoelectroautotrophy. However, under photoferroautotrophy, the specific PHB productivity was higher in the $\mathrm{Fe}(\mathrm{II})-\mathrm{NH}_{4} \mathrm{Cl}$ system compared to the $\mathrm{Fe}(\mathrm{II})-\mathrm{N}_{2}$ (Table 2). In addition, PHB carbon yield decreased in the $\mathrm{Fe}(\mathrm{II})-\mathrm{N}_{2}$ system compared to the $\mathrm{Fe}(\mathrm{II})-\mathrm{NH}_{4} \mathrm{Cl}$ system (Fig. 2a; Table 2). By carefully examining Fe(II) oxidation in $\mathrm{Fe}(\mathrm{II})-\mathrm{NH}_{4} \mathrm{Cl}$ system, a significant drop in $\mathrm{Fe}(\mathrm{II})$ concentration via microbial $\mathrm{Fe}$ (II) oxidation was observed during the first $96 \mathrm{~h}$, and $\mathrm{Fe}(\mathrm{II})$ was completely oxidized by $384 \mathrm{~h}$ (Fig. 4a). In contrast, the $\mathrm{Fe}(\mathrm{II})-\mathrm{N}_{2}$ system showed a very slow $\mathrm{Fe}$ (II) oxidation where a significant drop in $\mathrm{Fe}$ (II) concentration was observed only after $360 \mathrm{~h}$ (Fig. 4b). In addition, there was a decrease in the maximum $\mathrm{OD}_{660}$ in the $\mathrm{Fe}(\mathrm{II})-\mathrm{N}_{2}$ system compared to the $\mathrm{Fe}(\mathrm{II})-\mathrm{NH}_{4} \mathrm{Cl}$ system (Table 1). Additionally, total protein concentration with the 
(a) Growth during photoelectroautotrophy

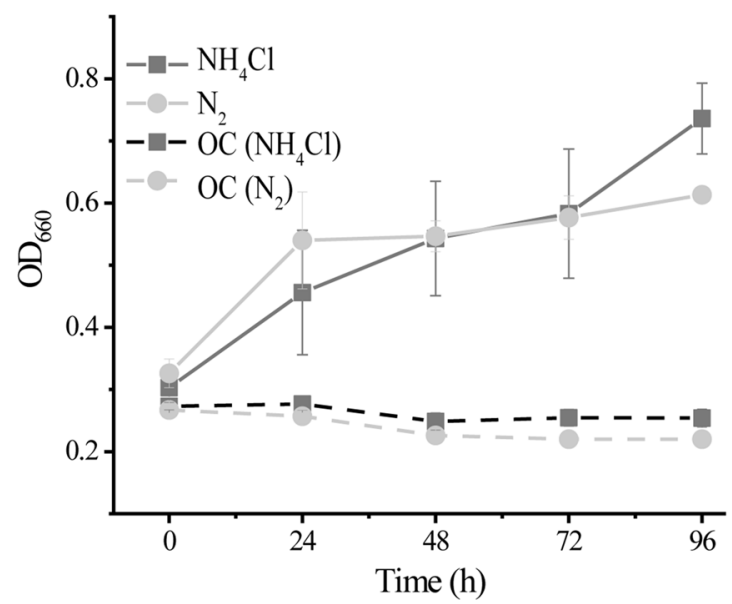

Fig. 3 a TIE-1 growth during photoelectroautotrophy. $\mathrm{OD}_{660}$ values of TIE-1 grown under photoelectroautotrophy in freshwater medium (FW) with $\mathrm{NH}_{4} \mathrm{Cl}$ and under $\mathrm{N}_{2}$ fixing conditions with their respective control with unpoised electrodes (open circuit, OC). Error bars are from the standard deviations calculated using three biological replicates. b Current density during photoelectroautotrophy. Current density $\left(\mu \mathrm{A} / \mathrm{cm}^{2}\right)$ from TIE-1 grown with freshwater medium with $\mathrm{NH}_{4} \mathrm{Cl}$ as a nitrogen source or with $\mathrm{N}_{2}$ gas as a nitrogen source using

(a) Growth with $\mathrm{NH}_{4} \mathrm{Cl}$

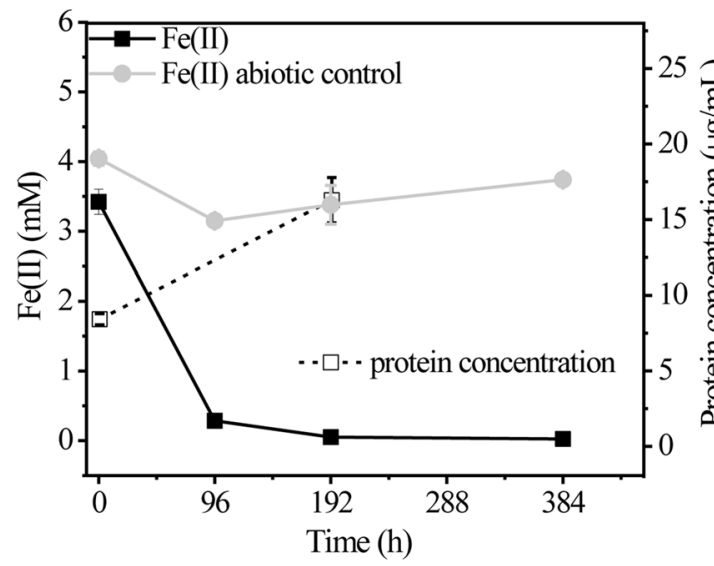

Fig. 4 Growth of TIE-1 under photoferroautotrophic conditions. $\mathrm{Fe}$ (II) oxidation and protein concentration measured during photoferroautotrophy a with $\mathrm{NH}_{4} \mathrm{Cl}$ as a nitrogen source, and $\mathbf{b}$ with $\mathrm{N}_{2}$ gas as a nitrogen source. Error bars are from the standard deviations calcu-

$\mathrm{Fe}(\mathrm{II})-\mathrm{NH}_{4} \mathrm{Cl}$ nearly doubled after $192 \mathrm{~h}$ whereas, with the $\mathrm{Fe}(\mathrm{II})-\mathrm{N}_{2}$, the total protein concentration doubled only after $360 \mathrm{~h}$ (Fig. 4a, b). Based on these results, it is plausible that the growth defect in the $\mathrm{Fe}(\mathrm{II})-\mathrm{N}_{2}$ system is a consequence of the high-energy demand during $\mathrm{N}_{2}$ fixation (Table 1; Fig. 4). (b) Current density during photoelectroautotrophy

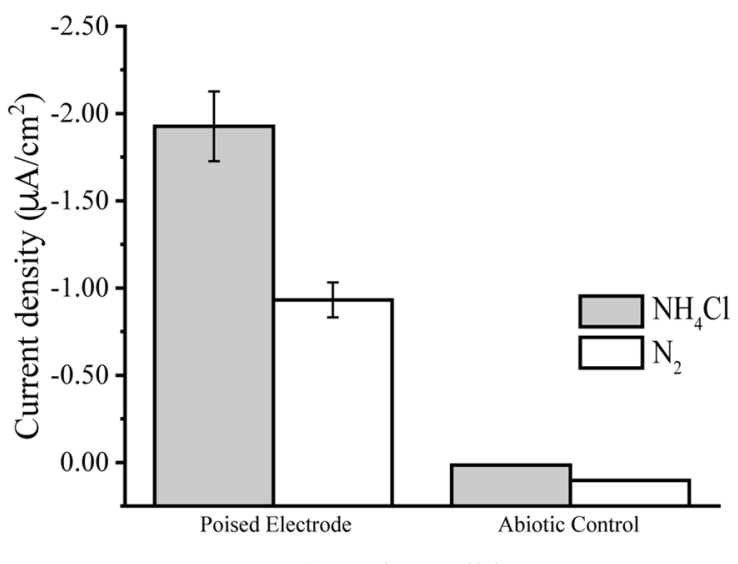

Growth conditions

a poised electrode at a potential of $+100 \mathrm{mV}$ vs. Standard hydrogen electrode (SHE) and the associated abiotic control. The negative sign on the $Y$-axis indicates current uptake. Error bars are the standard deviations calculated using two biological replicates. The $P$ values were determined by one-way ANOVA followed by a pairwise test with Bonferroni adjustment; $n s$ not significant. For a pairwise test, the cutoff $P$ value is 0.025 . $P$ values are indicated in Table S5

(b) Growth under $\mathrm{N}_{2}$ fixing conditions

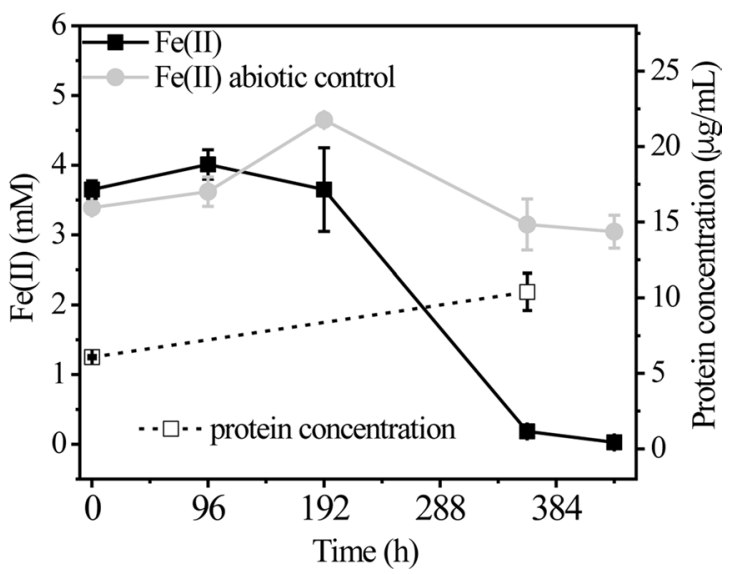

lated using three biological replicates. The $P$ values were determined by one-way ANOVA followed by a pairwise test with Bonferroni adjustment; $n s$ not significant. For a pairwise test, the cutoff $P$ value is 0.025$). P$ values are indicated in Table S5

\section{Comparison of PHB production under photoautotrophic conditions}

Among the three electron donors tested, photoautotrophic growth with $\mathrm{H}_{2}$ showed the highest maximum $\mathrm{OD}_{660}$ when grown with $\mathrm{NH}_{4} \mathrm{Cl}$ (Table $1, P \leq 0.001$ ). Although the $\mathrm{Fe}(\mathrm{II})-\mathrm{NH}_{4} \mathrm{Cl}$ and the $\mathrm{Fe}(\mathrm{II})-\mathrm{N}_{2}$ conditions resulted in the lowest maximum $\mathrm{OD}_{660}$ (Table $1, P \leq 0.001$ ), the 
PHB carbon yield under the $\mathrm{Fe}(\mathrm{II})-\mathrm{NH}_{4} \mathrm{Cl}$ is comparable to that obtained from photoautotrophy in the $\mathrm{H}_{2}-\mathrm{NH}_{4} \mathrm{Cl}$ system (Table 2, $P=0.0613$ ) and higher than under the electrode- $\mathrm{NH}_{4} \mathrm{Cl}$ (Table 2, $P=0.028$ ). Moreover, the specific PHB productivity obtained in the $\mathrm{Fe}(\mathrm{II})-\mathrm{NH}_{4} \mathrm{Cl}$ is the highest amongst all the photoautotrophic conditions with $\mathrm{NH}_{4} \mathrm{Cl}$ (Table $2, P \leq 0.001$ ). The electrode- $\mathrm{N}_{2}$ system showed the longest generation times amongst all the photoautotrophic growth conditions (Table $1, P \leq 0.001$ ). Photoelectroautotrophy showed the lowest PHB carbon yield both with $\mathrm{NH}_{4} \mathrm{Cl}$ and $\mathrm{N}_{2}$ (Fig. 2a, $P=0.0045$ ). Nevertheless, TIE-1 showed the highest efficiency in converting electrons to PHB in the electrode- $-\mathrm{NH}_{4} \mathrm{Cl}$ system (4.39\% PHB electron yield) and in the electrode- $\mathrm{N}_{2}$ system (7.34\% PHB electron yield) (Table 2, $P \leq 0.001$ ). These results indicate that although the growth of TIE-1 during photoelectroautotrophy was slow, this condition was the most efficient at converting electrons obtained from a poised electrode into PHB. A previous comparative growth study of TIE- 1 using $\mathrm{H}_{2}$ and soluble $\mathrm{Fe}$ (II) as electron donors revealed $\mathrm{H}_{2}$ as a preferred electron donor over $\mathrm{Fe}$ (II) [32]. This preference was reflected in the lower PHB carbon yield during photoferroautotrophy vs. photoautotrophy with $\mathrm{H}_{2}$ (Fig. 2; Table 2).

\section{Effect of $\mathrm{N}_{2}$ fixation on photoautotrophic PHB production}

The effect of $\mathrm{N}_{2}$ fixation was clearly observed in both $\mathrm{H}_{2}$ and $\mathrm{Fe}$ (II) systems, where cell growth and the PHB carbon yield was significantly reduced under $\mathrm{N}_{2}$ fixing conditions (Tables 1,2). Based on previous studies, it is likely that the stress caused by the high-energy $\mathrm{N}_{2}$ fixation process led to the accumulation of PHB by TIE- 1 [29, 51]. However, $\mathrm{N}_{2}$ fixation did not have a significant impact on the growth of TIE-1, the specific PHB productivity and the PHB carbon yield under photoelectroautotrophy (Table 2). A continuous electron supply might have allowed TIE- 1 to fix $\mathrm{N}_{2}$ to ammonium without affecting the supply of electrons to produce PHBs. Interestingly, PHB biosynthesis was proposed to be a potential electron sink when Rhodopseudomonas palustris CGA009 was incubated in the presence of argon (nitrogen deprived) [51]. However, our results show that only a small percentage of electrons go to PHB biosynthesis under all $\mathrm{N}_{2}$ fixing conditions (Table 2). In the electrode- $\mathrm{N}_{2}$ system, where the maximum PHB electron yield was obtained, only 7.34\% of the available electrons contributed to PHB biosynthesis.

\section{TIE-1 produces PHB under chemoheterotrophic and photoheterotrophic conditions}

\section{Chemoheterotrophic PHB production}

To further investigate the effect of different media on PHB production, TIE-1 was grown chemoheterotrophically (aerobic) with rich media containing yeast extract and peptone (YP). Aerobic growth of TIE-1 on YP resulted in the longest generation time ( $g=11.18 \mathrm{~h})$ compared to the generation time observed from all the other photoheterotrophic conditions (Table $1, P \leq 0.001$ ). YP-grown cells produced the highest specific PHB productivity of $24.60 \times 10^{-14}$ $\mathrm{mg} / \mathrm{L} / \mathrm{Cell} / \mathrm{h}$ compared to all the conditions tested (Table 2 , $P \leq 0.001)$. It is likely that the amino acids provided by peptone contributed to the increased PHB production by TIE-1 under this condition. The availability of amino acids precludes their de novo biosynthesis, and peptone has been previously reported to increase PHB production in Azotobacter vinelandii [56].

\section{Photoheterotrophic PHB production with succinate}

To test the effect of different carbon sources with different oxidation/reduction values (Supplemental Table S4) on PHB production, TIE-1 was further grown photoheterotrophically (anaerobic) using three different substrates: succinate, butyrate, and 3-hydroxybutyrate with $\mathrm{NH}_{4} \mathrm{Cl}$ and $\mathrm{N}_{2}$ gas. Similar to photoautotrophy, use of $\mathrm{N}_{2}$ gas as the source of nitrogen resulted in longer lag time, longer generation time and a longer time to reach maximum $\mathrm{OD}_{660}$ compared to $\mathrm{NH}_{4} \mathrm{Cl}$ as the nitrogen source (Table 1). However, there was no significant difference in specific PHB productivity between the succinate- $\mathrm{N}_{2}$ system and the succinate- $\mathrm{NH}_{4} \mathrm{Cl}$ system (Table 2). Rather there was an increase in the PHB carbon yield and PHB electron yield in the succinate- $\mathrm{N}_{2}$ system compared to the succinate- $\mathrm{NH}_{4} \mathrm{Cl}$ system (Fig. 2b; Table 2) indicating that there was no significant effect of $\mathrm{N}_{2}$ fixation on PHB productivity (Table 2).

\section{Photoheterotrophic PHB production with butyrate and 3-hydroxybutyrate}

Interestingly, TIE-1 grown photoheterotrophically with the less oxidized substrate, butyrate, showed a decrease in maximum $\mathrm{OD}_{660}(0.42)$ in the butyrate- $\mathrm{NH}_{4} \mathrm{Cl}$ compared to 0.69 with the butyrate- $\mathrm{N}_{2}$ systems (Table 1). An increase of about ninefold in PHB carbon yield was obtained in the butyrate- $\mathrm{N}_{2}$ system compared to the butyrate- $\mathrm{NH}_{4} \mathrm{Cl}$ system (Fig. 2b; Table 2). Similarly, specific PHB productivity in the butyrate- $\mathrm{N}_{2}$ system was more than three times higher compared to the butyrate- $\mathrm{NH}_{4} \mathrm{Cl}$ system (Table 2). The highest PHB production $(\sim 17.1 \mathrm{mg} / \mathrm{L})$, as well as the highest PHB carbon yield, was obtained in the butyrate- $\mathrm{NH}_{4} \mathrm{Cl}$ system (Table 2). Although this PHB production is lower than the PHB production previously reported by another photosynthetic purple bacterium, Rhodobacter sphaeroides $(60 \mathrm{mg} / \mathrm{L})$ grown in olive mill wastewater under $\mathrm{N}_{2}$-limited conditions [22], TIE-1's ability to produce PHB under various conditions such as photoautotrophy offers an obvious 
advantage when considering mixotrophic (photoheterotrophy and photoautotrophy) growth conditions for PHB production. Butyrate has been previously reported to be a preferred substrate over acetate in a PHB-producing mixed culture dominated by Plasticicumulans acidivorans due to the lower ATP need for PHB production using butyrate [49]. In addition, a study performed on $C$. necator has shown that butyrate is metabolized into 3-hydroxybutyryl-CoA via the beta-oxidation pathway. 3-Hydroxybutyryl-CoA is a direct precursor for PHB biosynthesis [16]. This shorter pathway might explain the higher PHB production along with faster generation time and a higher maximum $\mathrm{OD}_{660}$ obtained from butyrate compared to succinate and 3-hydroxybutyrate (Table 1; Table 2). Moreover, the higher numbers of electrons in butyrate compared to succinate and 3-hydroxybutyrate could contribute to higher PHB production in TIE-1 $[29,51]$. A previous study by Shi et al. also reported similar results using metabolic flux balance analysis of PHB biosynthesis by $C$. necator under nitrogen-limited conditions using butyrate [71].

When TIE-1 was grown photoheterotrophically in 3-hydroxybutyrate, shorter lag time was observed in the 3-hydroxybutyrate- $\mathrm{NH}_{4} \mathrm{Cl}$ compared to the 3-hydroxybutyrate- $\mathrm{N}_{2}$ (Table 1). Although the maximum $\mathrm{OD}_{660}$ values were similar, $\mathrm{N}_{2}$ fixing conditions significantly increased the time to reach the maximum $\mathrm{OD}_{660}$ values (Table 1). A decrease in PHB electron yield was observed when TIE-1 was grown in the 3-hydroxybutyrate- $\mathrm{NH}_{4} \mathrm{Cl}$ system compared to the 3-hydroxybutyrate- $\mathrm{N}_{2}$ (Table 2). However, no significant differences were observed in the PHB carbon yield and specific productivity under these conditions (Table 2). These results indicate that $\mathrm{N}_{2}$ fixation slowed the growth of TIE-1 in 3-hydroxybutyrate but increased the PHB electron yield similar to the results obtained under other heterotrophic growth conditions (Table 1; Table 2).

\section{Effect of $\mathrm{N}_{2}$ fixation on photoheterotrophic PHB production}

Overall, $\mathrm{N}_{2}$ fixing conditions during photoheterotrophy delayed cell growth and resulted in a longer lag time as well as a longer time to achieve maximum $\mathrm{OD}_{660}$ (two times or longer) (Table 1). In contrast, PHB carbon yield under photoheterotrophy under $\mathrm{N}_{2}$ fixing conditions was higher than with $\mathrm{NH}_{4} \mathrm{Cl}$ (Table 2). This increase in PHB production under $\mathrm{N}_{2}$ fixing or $\mathrm{N}_{2}$ deprivation conditions is consistent with previous findings [29,51]. This trend was not observed under photoautotrophic conditions. Interestingly, our results show that only a small percentage of carbon from the different substrates contributes to PHB synthesis by TIE-1. For example, the maximum PHB carbon yield during photoheteroautotrophic growth with butyrate was $8.81 \%$. This indicates that the remaining carbon is likely used for biomass production. A previous report has shown that $R$. palustris grown on acetate converts $93 \%$ of its carbon into biomass [50].

\section{STEM-EELS confirms intracellular accumulation of PHB granules in TIE-1}

Because the LC-MS method used for PHB quantification involves digestion of the PHB polymer into crotonic acid [35], it was necessary to confirm the presence of intracellular PHB granules in TIE-1 using an additional technique. Nile red staining has previously been used to screen for PHB and fatty acid esters in bacteria [61]. However, this staining technique was ineffective in showing any intracellular inclusion bodies in TIE-1 possibly due to its small size. Hence, scanning transmission electron microscopy-electron energy loss spectroscopy (STEM-EELS) under conditions that produced the highest accumulation of PHB $(\mathrm{mg} / \mathrm{L} / \mathrm{Cell})$ was performed. All the conditions imaged contained $\mathrm{NH}_{4} \mathrm{Cl}$. The intracellular localization of PHB granules was confirmed by the carbon and nitrogen maps (Fig. 5). The nitrogen signal is likely from the phasin protein that is known to bind PHB granules [63]. PHB mostly aggregated as small multiple granules under photoelectroautotrophy compared to larger granules under photoferroautotrophy and photoheterotrophy with butyrate (Fig. 5). A change in the number and morphology of PHB granules was also observed previously in an anoxygenic phototrophic bacteria Dinoroseobacter sp. JL1447 when it was grown with different carbon sources such as sodium acetate, glucose, sodium glutamate, sodium pyruvate, and trisodium citrate [85]. Moreover, in a study on a purple non-sulfur bacterium Rhodovulum visakhapatnamense, a change in size and an increase in the number of PHB granules were also observed under nitrogen stress [29].

\section{PHB cycle genes are not differentially expressed}

Our data show that there is significant variation in PHB production by TIE- 1 under different growth conditions (Fig. 2; Table 2). To determine if genes involved in PHB production are transcriptionally regulated, transcript levels of the genes involved in the PHB cycle was assessed using RNA-Seq and reverse transcription quantitative PCR (RT-qPCR). PHB cycle genes were chosen and are summarized in Fig. 1a. RNA-Seq analysis showed that the PHB cycle genes were not differentially expressed with respect to growth conditions or levels of PHB (values having $p>0.05$ are statistically not significant) (Fig. 6, Tables S7-S10). RTQPCR was performed to corroborate these data. For this analysis, we chose one phaA isozyme (Rpal_0532) of many because it showed the highest expression in the RNAseq data. This gene exists in an operon with a phaB homolog (Rpal_0533) (Fig. 1b), which was the only phaB homolog that was chosen for RT-qPCR analysis. The other PHB cycle 
Fig. 5 STEM-EELS images of TIE-1 grown photoheterotrophically with butyrate, photoferroautotrophically with $\mathrm{Fe}(\mathrm{II})$ and photoelectroautotrophically with a poised electrode. From top to bottom panel: bright-field image, carbon, and nitrogen map, and the composite images. Bright areas represent the dominance of the corresponding element (carbon, and nitrogen). The red background in the composite images is due to carbon signals from Spurr's resin used for embedding the cells during sample preparation. The scale bars are $0.2 \mu \mathrm{m}$

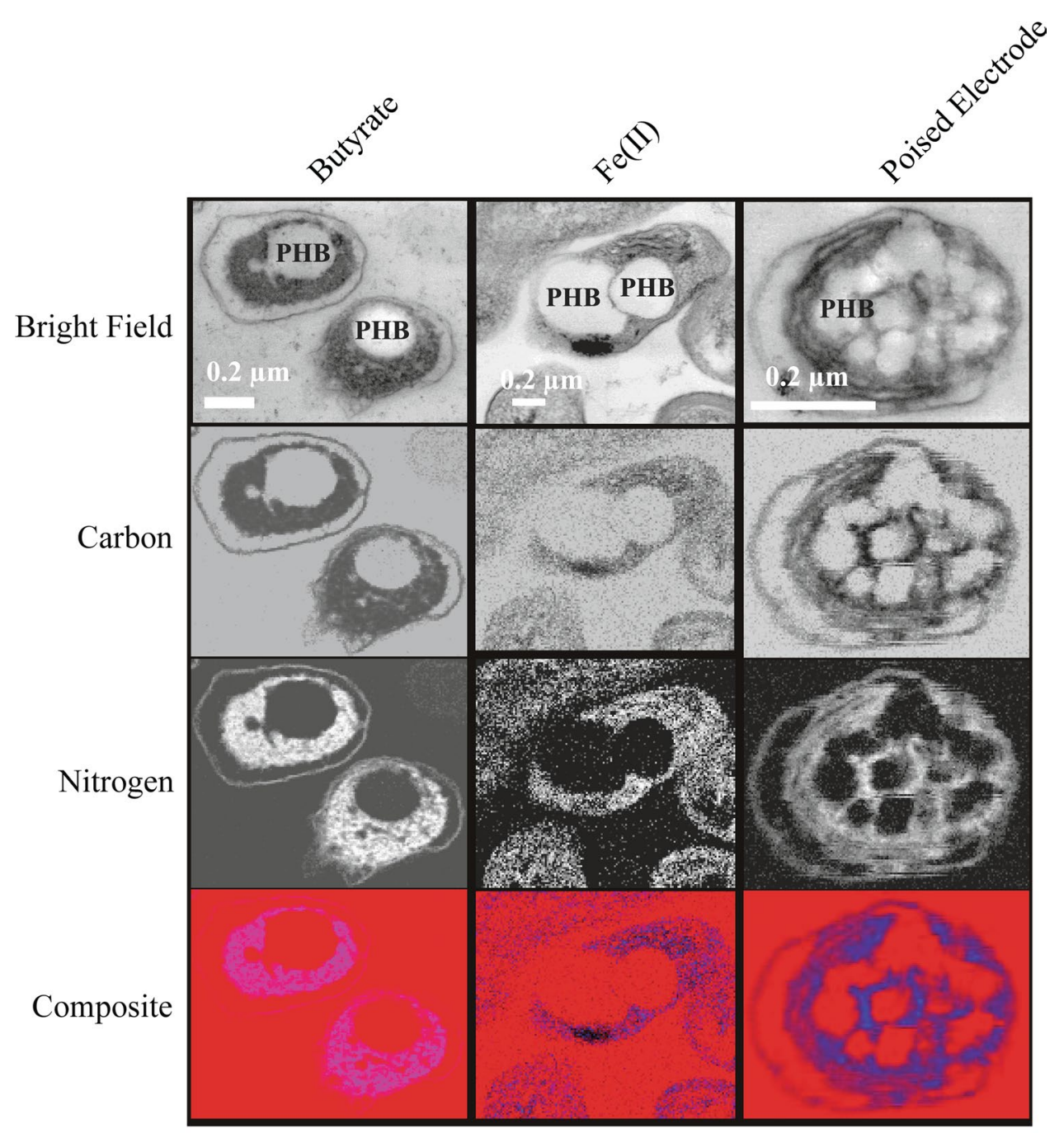

STEM-EELS Images of TIE-1 showing PHB granules genes only had 1-2 representatives in the TIE-1 chromosome and these were all analyzed using RT-qPCR. RNAseq analysis combined with RT-qPCR analysis of these phaAB homologs (Table S11) revealed no significant changes in gene expression (Figure S1; Tables S8, S9). Moreover, the analysis of $p h a C_{1}$ and $p h a C_{2}$ polymerase genes did not show any significant differential expression (Fig. 6, Tables S7, $\mathrm{S} 10)$. McKinlay et al. reported that $R$. palustris CG009 when incubated photoheterotrophically with acetate, under $\mathrm{N}_{2}$ deprivation (with argon), accumulated $\mathrm{PHBs}$ with no change in transcript levels of genes known to be involved in PHB biosynthesis [51].

Phasin proteins have been reported to play a significant role in the PHB cycle [86]. Deletion of the phaP gene reduced $\mathrm{PHB}$ production significantly in $C$. necator [86]. Here, no significant upregulation of $p h P_{2}$ genes was observed using RNAseq even during photoheterotrophic growth with the butyrate- $\mathrm{N}_{2}$ system, where the highest $\mathrm{PHB}$ production in $\mathrm{mg} / \mathrm{L} / \mathrm{cell}$ was obtained (Supplemental
Table S7). Although phaP ${ }_{2 a}$ appears to show a slight upregulation of 2.33-fold change under photoelectroautotrophy with $\mathrm{N}_{2}$ fixing conditions, the $P$ value was more than 0.05 , rendering it not significant (Fig. 6, Table S7). Gene expression analysis results during photoautotrophy and photoheterotrophy using both RNAseq and RT-qPCR show that there is no differential expression in the genes involved in the PHB cycle. This could suggest that in TIE-1 (and perhaps even CGA009), the variation in PHB accumulation might be regulated post-transcriptionally. These findings are useful for the further optimization of PHB production using TIE-1 [45].

\section{Conclusions and future perspectives}

Our study demonstrates the ability of a metabolically versatile photoautotroph Rhodopseudomonas palustris TIE-1 to produce PHB intracellularly under various growth conditions using different electron donors. The 


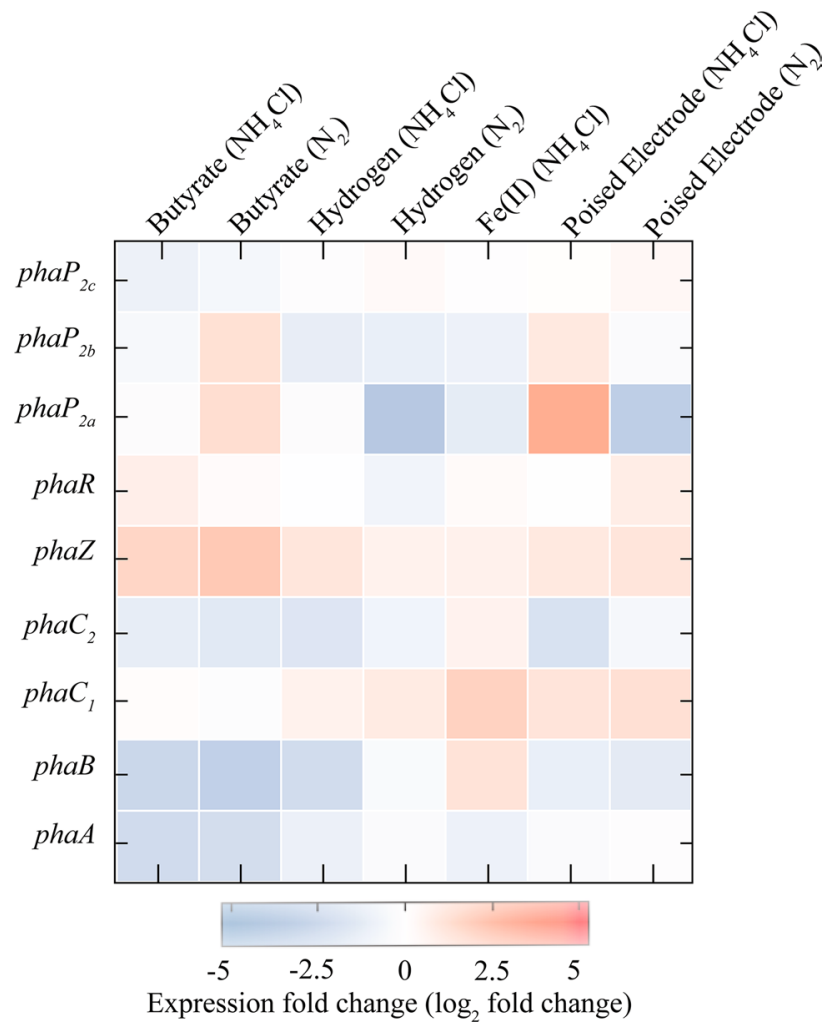

Fig. 6 Heat map showing $\log _{2}$ fold change in the expression of PHB genes from RNA sequencing analysis (RNASeq). Results are from TIE-1 grown in freshwater (FW) medium photoheterotrophically with butyrate, photoautotrophically with $\mathrm{H}_{2}$, photoferroautotrophically with $\mathrm{Fe}(\mathrm{II})$, and photoelectroautotrophically using a poised electrode. Growth with $\mathrm{NH}_{4} \mathrm{Cl}$ is indicated by $\mathrm{NH}_{4} \mathrm{Cl}$ whereas growth under $\mathrm{N}_{2}$ fixing conditions is indicated by $\mathrm{N}_{2}$. Error bars are the standard deviations calculated using three biological replicates. The $P$ values were determined by one-way ANOVA followed by a pairwise test with Bonferroni adjustment; $n s$ not significant. For a pairwise test, the cutoff $P$ value is 0.025$). P$ values are indicated in Table S7-9

novel photoautotrophic metabolism using a poised electrode as the source of electrons produced the highest PHB electron yield. Another key discovery of this study is the ability of TIE-1 to yield the highest specific PHB productivity using $\mathrm{Fe}$ (II) as an electron donor for photoautotrophy. In summary, these newly described routes can serve as potential substitutes for PHB bioproduction. The application of these novel approaches can be especially important in areas where organic carbon sources are limited while resources such as light, $\mathrm{CO}_{2}$ [37], iron, and electricity [57] are abundant. TIE-1's ability to fix $\mathrm{N}_{2}$ gas photoautotrophically makes it a more attractive biocatalyst for many applications including PHB biosynthesis. The extreme metabolic versatility of TIE- 1 can also be considered for waste management efforts combined with MES (for example for PHB biosynthesis). This approach can be further scaled up using underwater tubular photobioreactors that have been used previously to investigate the photosynthetic efficiency of $R$. palustris 42OL [10]. The future of using biocatalysts like TIE-1 via direct EU for bioproduction needs further consideration. We are pursuing modifications of electrodes and changes in reactor design to improve direct EU by TIE-1 as this represents the first major hurdle in the application of such microbes for bioproduction [65]. Using TIE-1 in the context of photoferroautotrophy also needs further investigation as our data support the idea that biomolecule production can be linked to this process.

Acknowledgements We are grateful to Dr. Joshua Blodgett and Yifei $\mathrm{Hu}$ for their support during PHB analysis using LC-MS. We appreciate funding provided by The David and Lucile Foundation (201563111) as well as the Department of Energy (Grant number DESC0014613), and the U.S. Department of Defense, Army Research Office (Grant number W911NF-18-1-0037). M.S.G. was supported by NIH Initiative for Maximizing Student Development (IMSD) training Grant R25-GM103757.

Author contributions TOR performed all the experiments. RK assisted with the bioelectrochemical experiments. MSG assisted with RNASeq data analysis. RS assisted with STEM-EELS experiments. TOR, RS, and $\mathrm{AB}$ wrote the manuscript with input from all authors.

\section{Compliance with ethical standards}

Conflict of interest The authors declare that the research was conducted in the absence of any commercial or financial relationships that could be construed as a potential conflict of interest.

Open Access This article is distributed under the terms of the Creative Commons Attribution 4.0 International License (http://creativeco mmons.org/licenses/by/4.0/), which permits unrestricted use, distribution, and reproduction in any medium, provided you give appropriate credit to the original author(s) and the source, provide a link to the Creative Commons license, and indicate if changes were made.

\section{References}

1. Alkotaini B, Abdellaoui S, Hasan K, Grattieri M, Quah T, Cai R, Yuan M, Minteer SD (2018) Sustainable bioelectrosynthesis of the bioplastic polyhydroxybutyrate: overcoming substrate requirement for NADH regeneration. ACS Sustain Chem Eng 6:4909-4915

2. Applied Biosystem (2008) Guide to performing relative quantitation of gene expression using real-time quantitative PCR. Available via DIALOG. https://assets.thermofisher.com/TFS-Assets/ LSG/manuals/cms_042380.pdf. Accessed 28 Mar 2019

3. Aryal N, Tremblay PL, Lizak DM, Zhang T (2017) Performance of different Sporomusa species for the microbial electrosynthesis of acetate from carbon dioxide. Bioresour Technol 233:184-190

4. Bhattacharya S, Dubey S, Singh P, Shrivastava A, Mishra S (2016) Biodegradable polymeric substances produced by a marine bacterium from a surplus stream of the biodiesel industry. Bioengineering 3:34-44

5. Bolger A, Lohse MM, Usadel B (2014) Trimmomatic: a flexible trimmer for Illumina sequence data. Bioinformatics 30:2114-2120 
6. Bose A, Gardel EJ, Vidoudez C, Parra E, Girguis PR (2014) Electron uptake by iron-oxidizing phototrophic bacteria. Nat Commun 5:3391-3397

7. Bose A, Newman DK (2011) Regulation of the phototrophic iron oxidation (pio) genes in Rhodopseudomonas palustris TIE- 1 is mediated by the global regulator, FixK. Mol Microbiol 79:63-75

8. Bowien B, Kusian B (2002) Genetics and control of $\mathrm{CO}_{2}$ assimilation in the chemoautotroph Ralstonia eutropha. Arch Microbiol 178:85-93

9. Calvin M, Benson AA (1948) The path of carbon in photosynthesis. Science 107:476-480

10. Carlozzi P, Pushparaj B, Degl'Innocenti A, Capperucci A (2006) Growth characteristics of Rhodopseudomonas palustris cultured outdoors, in an underwater tubular photobioreactor, and investigation on photosynthetic efficiency. Appl Microbiol Biotechnol 73:789-795

11. Chen GQ (2010) Plastics completely synthesized by bacteria: polyhydroxyalkanoates. Plastics from bacteria. Springer, Berlin, Heidelberg, pp 17-37

12. Chen X, Cao Y, Li F, Tian Y, Song H (2018) Enzyme-assisted microbial electrosynthesis of poly (3-hydroxybutyrate) via $\mathrm{CO}_{2}$ bioreduction by engineered Ralstonia eutropha. ACS Catal 8:4429-4437

13. Clauwaert P, Toledo R, Van der Ha D, Crab R, Verstraete W, Hu H, Udert K, Rabaey K (2008) Combining biocatalyzed electrolysis with anaerobic digestion. Water Sci Technol 57:575-579

14. Darani KK, Vasheghani-Farahani E, Tanaka K (2006) Hydrogen oxidizing bacteria as poly(hydroxybutyrate) producers. Iran J Biotechnol 4:193-196

15. De Philippis RA, Ena A, Guastiini M, Sili C, Vincenzini M (1992) Factors affecting poly- $\beta$-hydroxybutyrate accumulation in cyanobacteria and in purple non-sulfur bacteria. FEMS Microbiol Lett 103:187-194

16. Doi Y, Tamaki A, Kunioka M, Soga K (1988) Production of copolyesters of 3-hydroxybutyrate and 3-hydroxyvalerate by Alcaligenes eutrophus from butyric and pentanoic acids. Appl Microbiol Biotechnol. 28:330-334

17. Dornburg V, Lewandowski I, Patel M (2003) Comparing the land requirements, energy savings, and greenhouse gas emissions reduction of biobased polymers and bioenergy: An analysis and system extension of life-cycle assessment studies. J Ind Ecol 7:93-116

18. Doud DFR, Angenent LT (2014) Toward electrosynthesis with uncoupled extracellular electron uptake and metabolic growth: enhancing current uptake with Rhodopseudomonas palustris. Environ Sci Technol Lett 1:351-355

19. Drosg B, Fritz I, Gattermayr F, Silvestrini L (2015) Photo-autotrophic production of poly (hydroxyalkanoates) in cyanobacteria. Chem Biochem Eng Q 29:145-156

20. Eddie BJ, Wang Z, Hervey WJ, Leary DH, Malanoski AP, Tender LM, Lin B, Strycharz-Glaven SM (2017) Metatranscriptomics supports the mechanism for biocathode electroautotrophy by "Candidatus Tenderia electrophaga". MSystems 2:e00002-e00017

21. Ehrenreich A, Widdel F (1994) Anaerobic oxidation of Fe(II) by purple bacteria, a new type of phototrophic metabolism. Appl Environ Microbiol 60:4517-4526

22. Eroğlu E, Gündüz U, Yücel M, Türker L, Eroğlu İ (2004) Photobiological hydrogen production by using olive mill wastewater as a sole substrate source. Int. J Hydrog Energy 29:163-171

23. Gralnick JA, Newman DK (2007) Extracellular respiration. Mol Microbiol 65:1-11

24. Greenwood NN, Earnshaw A (2012) Chemistry of the elements. Elsevier, Leeds

25. Ha PT, Lindemann SR, Shi L, Dohnalkova AC, Fredrickson JK, Madigan MT, Beyenal H (2017) Syntrophic anaerobic photosynthesis via direct interspecies electron transfer. Nat Commun 8:13924-13930

26. Hai T, Lange D, Rabus R, Steinbüchel A (2004) Polyhydroxyalkanoate (PHA) accumulation in sulfate-reducing bacteria and identification of a class III PHA synthase (PhaEC) in Desulfococcus multivorans. Appl Environ Microbiol 70:4440-4448

27. Hallbeck L, Ståhl F, Pedersen K (1993) Phytogeny and phenotypic characterization of the stalk-forming and iron-oxidizing bacterium Gallionella ferruginea. J Gen Microbiol 139:1531-1535

28. Harrington TD, Tran VN, Mohamed A, Renslow R, Biria S, Orfe L, Call DR, Beyenal H (2015) The mechanism of neutral redmediated microbial electrosynthesis in Escherichia coli: menaquinone reduction. Bioresour Technol 192:689-695

29. Higuchi-Takeuchi Morisaki MK, Toyooka K, Numata K (2016) Synthesis of high-molecular-weight polyhydroxyalkanoates by marine photosynthetic purple bacteria. PLoS One 11:e0160981-e0160997

30. Ishizaki A, Tanaka K (1991) Production of poly- $\beta$-hydroxybutyric acid from carbon dioxide by Alcaligenes eutrophus ATCC 17697T. J Ferment Bioeng 71:254-257

31. Jaitz L, Mueller B, Koellensperger G, Huber D, Oburger E, Puschenreiter M, Hann S (2011) LC-MS analysis of low molecular weight organic acids derived from root exudation. Anal Bioanal Chem 400:2587-2596

32. Jiao Y, Kappler A, Croal LR, Newman DK (2005) Isolation and characterization of a genetically tractable photoautotrophic Fe(II)oxidizing bacterium, Rhodopseudomonas palustris strain TIE-1. Appl Environ Microbiol 71:4487-4496

33. Jourdin L, Lu Y, Flexer V, Keller J, Freguia S (2016) Biologically induced hydrogen production drives high rate/high efficiency microbial electrosynthesis of acetate from carbon dioxide. ChemElectroChem 3:581-591

34. Kamravamanesh D, Pflügl S, Nischkauer W, Limbeck A, Lackner M, Herwig C (2017) Photosynthetic poly- $\beta$-hydroxybutyrate accumulation in unicellular cyanobacterium Synechocystis sp. PCC 6714. AMB Express 7:143-154

35. Karr B, Waters JK, Emerich DW (1983) Analysis of poly-3-hydroxybutyrate in Rhizobium japonicum bacteroids by ion-exclusion high-pressure liquid chromatography and UV detection. Appl Environ Microbiol 46:1339-1344

36. Kato S (2015) Biotechnological aspects of microbial extracellular electron transfer. Microbes Environ 30:133-139

37. Kheshgi HS, Prince RC (2005) Sequestration of fermentation $\mathrm{CO}_{2}$ from ethanol production. Energy 30:1865-1871

38. Khosravi-Darani K, Mokhtari ZB, Amai T, Tanaka K (2013) Microbial production of poly (hydroxybutyrate) from $\mathrm{C}_{1}$ carbon sources. Appl Microbiol Biotechnol 97:1407-1424

39. Khunjar WO, Sahin A, West AC, Chandran K, Banta S (2012) Biomass production from electricity using ammonia as an electron carrier in a reverse microbial fuel cell. PLoS One 7:e44846-e44853

40. Klugkist J, Haaker H (1984) Inhibition of nitrogenase activity by ammonium chloride in Azotobacter vinelandii. J Bacteriol 157:148-151

41. Kucera D, Benesova P, Ladicky P, Pekar M, Sedlacek P, Obruca S (2017) Production of polyhydroxyalkanoates using hydrolyzates of spruce sawdust: comparison of hydrolyzates detoxification by application of overliming, active carbon, and lignite. Bioengineering 4:53-61

42. Kwan TH, Hu Y, Lin CSK (2018) Techno-economic analysis of a food waste valorization process for lactic acid, lactide and poly (lactic acid) production. J Clean Prod 181:72-87

43. Li H, Opgenorth PH, Wernick DG, Rogers S, Wu TY, Higashide W, Malati P, Huo YX, Cho KM, Liao JC (2012) Integrated 
electromicrobial conversion of $\mathrm{CO}_{2}$ to higher alcohols. Science 335:1596-1597

44. Love MI, Huber W, Anders S (2014) Moderated estimation of fold change and dispersion for RNA-seq data with DESeq2. Genome Biol 15:550-570

45. Luengo J, Garcia B, Sandoval A, Naharroy G, Olivera E (2003) Bioplastics from microorganisms. Curr Opin Microbiol 6:251-260

46. Lütters-Czekalla S (1990) Lithoautotrophic growth of the iron bacterium Gallionella ferruginea with thiosulfate or sulfide as energy source. Arch Microbiol 154:417-421

47. Madigan MT, Martinko JM, Parker J (1996) Nutrition and metabolism. Brock biology of microorganisms, 8th edn. Prentice-Hall, New Jersey, pp 109-177

48. Manavitehrani I, Fathi A, Badr H, Daly S, Negahi Shirazi A, Dehghani F (2016) Biomedical applications of biodegradable polyesters. Polymers 8:51-82

49. Marang L, Jiang Y, Van Loosdrecht MCM, Kleerebezem R (2013) Butyrate as a preferred substrate for polyhydroxybutyrate production. Bioresour Technol 142:232-239

50. McKinlay JB, Harwood CS (2010) Carbon dioxide fixation as a central redox cofactor recycling mechanism in bacteria. Proc Natl Acad Sci 107:11669-11675

51. McKinlay JB, Oda Y, Rühl M, Posto AL, Sauer U, Harwood CS (2014) Non-growing Rhodopseudomonas palustris increases the hydrogen gas yield from acetate by shifting from the glyoxylate shunt to the tricarboxylic acid cycle. J Biol Chem 289:1960-1970

52. Nevin KP, Hensley SA, Franks AE, Summers ZM, Ou J, Woodard TL, Snoeyenbos-West OL, Lovley DR (2011) Electrosynthesis of organic compounds from carbon dioxide is catalyzed by a diversity of acetogenic microorganisms. Appl Environ Microbiol 77:2882-2886

53. Nevin KP, Woodard TL, Franks AE, Summers ZM, Lovley DR (2010) Microbial electrosynthesis: feeding microbes electricity to convert carbon dioxide and water to multicarbon extracellular organic compounds. MBio 1:e00103-e00110

54. Nielsen C, Rahman A, Rehman AU, Walsh MK, Miller CD (2017) Food waste conversion to microbial polyhydroxyalkanoates. Microb Biotech 10:1338-1352

55. Nishio K, Kimoto Y, Song J, Konno T, Ishihara K, Kato S, Hashimoto K, Nakanishi S (2013) Extracellular electron transfer enhances polyhydroxybutyrate productivity in Ralstonia eutropha. Environ Sci Tech Let 1:40-43

56. Page WJ (1992) Production of poly- $\beta$-hydroxybutyrate by Azotobacter vinelandii UWD in media containing sugars and co containing sugars and complex nitrogen sources. Appl Microbiol Biotechnol 38:117-121

57. Parida B, Iniyan S, Goic R (2011) A review of solar photovoltaic technologies. Renew Sust Energ Rev 15:1625-1636

58. Peguin S, Soucaille P (1996) Modulation of metabolism of Clostridium acetobutylicum grown in chemostat culture in a three-electrode potentiostatic system with methyl viologen as electron carrier. Biotechnol Bioeng 51:342-348

59. Peoples OP, Sinskey AJ (1989) Poly-beta-hydroxybutyrate (PHB) biosynthesis in Alcaligenes eutrophus H16. Identification and characterization of the PHB polymerase gene ( $p h b C)$. J Biol Chem 264:15298-15303

60. Peoples OP, Sinskey AJ (1989) Poly-beta-hydroxybutyrate biosynthesis in Alcaligenes eutrophus H16. Characterization of the genes encoding beta-ketothiolase and acetoacetyl-CoA reductase. J Biol Chem 264:15293-15297

61. Pinzon NM, Aukema KG, Gralnick JA, Wackett LP (2011) Nile red detection of bacterial hydrocarbons and ketones in a highthroughput format. MBio 2:e00109-e00111

62. Pozo G, Jourdin L, Lu Y, Keller J, Ledezma P, Freguia S (2016) Cathodic biofilm activates electrode surface and achieves efficient autotrophic sulfate reduction. Electrochim Acta 213:66-74

63. Quelas J, Mesa S, Mongiardini Jendrossek D, Lodeiro A (2016) Regulation of polyhydroxybutyrate synthesis in the soil bacterium Bradyrhizobium diazoefficiens. Appl Environ Microbiol 82:4299-4308

64. Rabaey K, Rozendal RA (2010) Microbial electrosynthesisrevisiting the electrical route for microbial production. Nat Rev Microbiol 8:706-716

65. Rengasamy K, Ranaivoarisoa T, Singh R, Bose A (2018) An insoluble iron complex coated cathode enhances direct electron uptake by Rhodopseudomonas palustris TIE-1. Bioelectrochem 122:164-173

66. Richter K, Schicklberger M, Gescher J (2012) Dissimilatory reduction of extracellular electron acceptors in anaerobic respiration. Appl Environ Microbiol 78:913-921

67. Sabbagh F, Muhamad II (2017) Production of poly-hydroxyalkanoate as secondary metabolite with main focus on sustainable energy. Renew Sust Energ Rev 72:95-104

68. Sakakibara Y, Kuroda M (1993) Electric prompting and control of denitrification. Biotechnol Bioeng 42:535-537

69. Salgaonkar BB, Bragança JM (2017) Utilization of sugarcane bagasse by Halogeometricum borinquense strain E3 for biosynthesis of poly (3-hydroxybutyrate-co-3-hydroxyvalerate). Bioengineering 4:50-67

70. Schlager S, Haberbauer M, Fuchsbauer A, Hemmelmair C, Dumitru LM, Hinterberger G, Neugebauer H, Sariciftci NS (2017) Bioelectrocatalytic application of microorganisms for carbon dioxide reduction to methane. Chemsuschem $10: 226-233$

71. Shi H, Shiraishi M, Shimizu K (1997) Metabolic flux analysis for biosynthesis of poly ( $\beta$-hydroxybutyric acid) in Alcaligenes eutrophus from various carbon sources. J Ferment Bioeng 84:579-587

72. Steinbusch KJJ, Hamelers HVM, Schaap JD, Kampman C, Buisman CJN (2010) Bioelectrochemical ethanol production through mediated acetate reduction by mixed cultures. Environ Sci Technol 44:513-517

73. Straub KL, Rainey FA, Widdel F (1999) Rhodovulum iodosum sp. nov. and Rhodovulum robiginosum sp. nov., two new marine phototrophic ferrous-iron-oxidizing purple bacteria. Int J Syst Bacteriol 49:729-735

74. Taepucharoen K, Tarawat S, Puangcharoen M, Incharoensakdi A, Monshupanee T (2017) Production of poly (3-hydroxybutyrate-co-3-hydroxyvalerate) under photoautotrophy and heterotrophy by non-heterocystous $\mathrm{N}_{2}$-fixing cyanobacterium. Bioresour Technol 239:523-527

75. Takahashi RYU, Castilho NAS, Silva MAC, Miotto MC, Lima AOS (2017) Prospecting for marine bacteria for polyhydroxyalkanoate production on low-cost substrates. Bioengineering 4:60-72

76. Tanaka K, Miyawaki K, Yamaguchi A, Khosravi-Darani K, Matsusaki H (2011) Cell growth and P (3HB) accumulation from $\mathrm{CO}_{2}$ of a carbon monoxide-tolerant hydrogen-oxidizing bacterium, Ideonella sp. O-1. Appl Microbiol Biotechnol 92:1161-1169

77. Todar K (2002) Growth of bacterial populations. In: Todar's online textbook of bacteriology. Available via DIALOG. http:// textbookofbacteriology.net/growth.html. Accessed 28 Mar 2019

78. Tremblay P-L, Zhang T (2015) Electrifying microbes for the production of chemicals. Front Microbiol 6:201-210

79. Verlinden RA, Hill DJ, Kenward M, Williams CD, Radecka I (2007) Bacterial synthesis of biodegradable polyhydroxyalkanoates. J Appl Microbiol 102:1437-1449

80. Villano M, Aulenta F, Ciucci C, Ferri T, Giuliano A, Majone $\mathrm{M}$ (2010) Bioelectrochemical reduction of $\mathrm{CO}_{2}$ to $\mathrm{CH}_{4}$ via 
direct and indirect extracellular electron transfer by a hydrogenotrophic methanogenic culture. Bioresource Technol 101:3085-3090

81. Wang Q, Yu H, Xia Y, Kang Z, Qi Q (2009) Complete PHB mobilization in Escherichia coli enhances the stress tolerance: a potential biotechnological application. Microb Cell Fact $8: 47-55$

82. Wickham H (2016) ggplot2: elegant graphics for data analysis. Springer, Texas

83. Widdel F, Schnell S, Heising S, Ehrenreich A, Assmus B, Schink B (1993) Ferrous iron oxidation by anoxygenic phototrophic bacteria. Nature 362:834-836

84. Wu SC, Liou SZ, Lee CM (2012) Correlation between biohydrogen production and polyhydroxybutyrate (PHB) synthesis by Rhodopseudomonas palustris WP3-5. Bioresour Technol 113:44-50

85. Xiao N, Jiao N (2011) Formation of polyhydroxyalkanoate in aerobic anoxygenic phototrophic bacteria and its relationship to carbon source and light availability. Appl Environ Microbiol $77: 7445-7450$
86. York G, Stubbe J, Sinskey A (2001) New insight into the role of the PhaP phasin of Ralstonia eutropha in promoting synthesis of polyhydroxybutyrate. J Bact 183:2394-2397

87. Yu L, Yuan Y, Tang J, Zhou S (2017) Thermophilic Moorella thermoautotrophica-immobilized cathode enhanced microbial electrosynthesis of acetate and formate from $\mathrm{CO}_{2}$. Bioelectrochemistry 117:23-28

88. Zhang T, Nie HR, Bain TS, Lu HY, Cui MM, SnoeyenbosWest OL, Franks AE, Nevin KP, Russell TP, Lovley DR (2013) Improved cathode materials for microbial electrosynthesis. Energ Environ Sci 6:217-224

Publisher's Note Springer Nature remains neutral with regard to jurisdictional claims in published maps and institutional affiliations. 